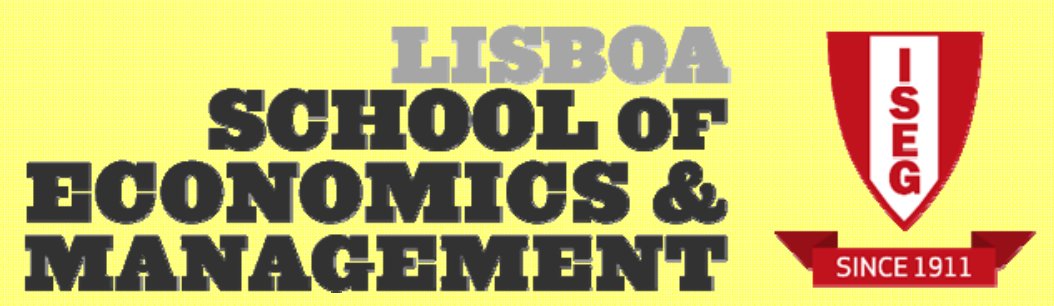

Department of Economics

António Afonso, António Jorge Silva

The Monetary Transmission Mechanism in the Euro Area: has it changed with the EMU? A VAR approach, with fiscal policy and financial stress considerations

WP10/2014/DE/UECE

WORKING PAPERS

ISSN 2183-1815

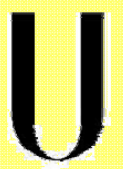

LISBOA

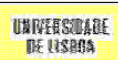




\title{
The Monetary Transmission Mechanism in the Euro Area: has it changed with the EMU? A VAR approach, with fiscal policy and financial stress considerations ${ }^{*}$
}

\author{
António Afonso $\$$, António Jorge Silva ${ }^{\#}$
}

June 2014

\begin{abstract}
We study whether the adoption of the Euro and a single monetary policy have brought about a change in the monetary transmission mechanism and between the interactions of monetary policy, fiscal policy and financial stress in the Euro area. We find that the stylized facts of monetary transmission remain valid, but the response of output and, especially, fiscal and financial stress variables to a monetary policy shock, seems to be stronger in the post-EMU period. Regarding fiscal and financial stress shocks, the inclusion in the post-EMU period of subprime and sovereign debt crises yields, changes, not only in the scale, but also in the patterns of the responses of our model's main variables.
\end{abstract}

JEL codes: E42, E44, E52, E58, E63

Keywords: monetary transmission mechanism, fiscal policy, financial stress, Euro area, vector autoregressions

\footnotetext{
* The opinions expressed herein are those of the authors and do not necessarily reflect those of the Banco de Portugal, the European Central Bank or the Euro system.

\$ ISEG/ULisboa - Universidade de Lisboa, Department of Economics; UECE - Research Unit on Complexity and Economics, R. Miguel Lupi 20, 1249-078 Lisbon, Portugal, email: aafonso@iseg.utl.pt. UECE is supported by the Fundacão para a Ciência e a Tecnologia (Portuguese Foundation for Science and Technology) through the PEst-OE/EGE/UI0436/2011 project, European Central Bank, Directorate General Economics, Kaiserstraße 29, D-60311 Frankfurt am Main, Germany.

\# ISEG/ULisboa - Universidade de Lisboa, R. Miguel Lupi 20, 1249-078 Lisbon, Portugal, email: ajorge.eu@gmail.com; Banco de Portugal, Statistics Department, 1150-165 Lisbon, Portugal, email: antonio.jorge.silva@bportugal.pt.
} 


\section{Introduction}

On December $31^{\text {st }}, 1998$, the conversion rates between the 11 participating national currencies and the Euro were fixed. On the following day, January $1^{\text {st }}, 1999$, the Euro became the official currency of the 11 countries in Europe ${ }^{1}$, and a single monetary policy was introduced under the authority of the European Central Bank (ECB).

Adopting the Euro as a single currency was a culmination point of several decades of economic and financial integration between European countries, and it marked the third and final stage of the Economic and Monetary Union (EMU). ${ }^{2}$

However, since the beginning of the process that led to the establishment of a single currency in Europe, there has been extensive discussion as to whether a single monetary policy would be suitable for the countries that adhere to the Euro, considering their differences in economic, financial and social structures.

For some time, such fundamental discussion took place mostly amongst academic and political circles in Europe and also in the USA. However, with the recent advent of the sovereign debt crisis in Europe after the 2008-2009 subprime crises, this discussion is ever more present in the common European citizen's everyday talk. Therefore, the referred culmination point may not be the final word on monetary integration in Europe and further developments are to be expected.

One of the fundamental aspects of the Euro, is the existence of a single monetary policy for the Euro area, conducted under the authority of the ECB. The Monetary Transmission Mechanism (MTM) is the process through which monetary policy affects real variables and prices in the economy and thus the understanding of this mechanism is pivotal to examining the single monetary policy under the ECB.

15 years have now passed the adoption of the Euro, and 12 years since the entry into circulation of Euro coins and banknotes. ${ }^{3}$ With the benefit of hindsight, we will try to

\footnotetext{
${ }^{1}$ The eleven founding countries of the Euro were: Austria, Belgium, Finland, France, Germany, Ireland, Italy, Luxembourg, the Netherlands, Portugal and Spain. Since then, other countries have adopted the Euro: Greece joined in 2001, Slovenia in 2007, Cyprus and Malta in 2008, Slovakia in 2008, Estonia in 2011 and Latvia in 2014.

${ }^{2}$ For the historical perspective on the economic and monetary integration in Europe see, amongst others, Apel (1998) and Ungerer (1997).
} 
assess whether the adoption of a single monetary policy has brought about a change in the MTM of the Euro area. Our perspective is Euro area wide and we will use a quarterly data sample from Q1 1987 to Q4 2011, to study the transmission mechanism pre, and post, Euro. The methodological approach will be a vector auto regression (VAR) model.

Furthermore, bearing in mind the impact of the subprime financial crisis and the sovereign-debt crisis in the Euro area in more recent years, we study at a macro-level the interactions between monetary policy, fiscal policy and stress in the financial sector for the area as a whole.

The rest of the paper is structured as follows: Section 2 presents the related literature; Section 3 reviews the econometric framework; Section 4 presents the data, the variables and the empirical results and Section 5 concludes.

\section{Related literature}

\subsection{Monetary Transmission Mechanism related VARs}

The process of establishing a single currency in Europe has, since the very beginning, generated ample discussions amongst economists as to whether a single monetary policy would be suitable for the countries that adhere to the Euro, and as to what could be the impacts of such a single policy. The economic literature on the MTM in Europe can be divided in two main approaches. One approach focuses on the MTM of the individual countries of the Euro area, i.e., on a country by country basis. Other studies follow an area wide perspective, i.e., they study the transmission mechanism of the Euro area as a whole. Both approaches have been used to analyze the transmission mechanism prior to, and after, Stage Three of the EMU. ${ }^{4}$

In 1999, the ECB launched a research initiative to study the transmission of monetary policy in the Euro area. Angeloni et al. (2003a) have an overall compilation of

\footnotetext{
${ }^{3}$ For the first three years, the Euro was only used for accounting purposes and did not have a physical existence. The Euro coins and banknotes were introduced in 1 January 2002.

${ }^{4}$ Other branches of literature focus on different specific channels of the monetary transmission mechanism. These are out of the scope of this paper. For good reviews of the literature related to different transmission channels see, for instance, Boivin et al. (2010) and Weber et al. (2009).
} 
several papers that were produced with this aim, and in Angeloni et al. (2003b) a complete summary and discussion of the main findings is provided.

Following the ECB's initiative, around the turn of the century, several authors focused their research on uncovering the stylized facts of the MTM in Europe and, in some cases, attempted to envisage the consequences for such mechanism of a single monetary policy. For instance, Mojon and Peersman (2003), following a country by country approach, find that the effects of monetary policy on GDP and prices were broadly similar in the individual countries of the Euro area. This indicates that monetary policy transmission might be similar between those countries before the EMU. Guiso et al. (1999) focus on whether a common monetary policy for the Euro area would have asymmetrical effects in the different countries and have a good literature overview on the topic. They report some significant differences across countries in several indicators that may matter for monetary transmission, even if no definitive conclusion seemed to be possible at the time. Peersman (2004) provides a comprehensive review of pre-EMU literature on cross-country comparisons.

Smets and Peersman (2003), following an area-wide approach, find that a temporary rise in the nominal and real short-term interest rate tended to be followed by a real appreciation of the exchange rate, a temporary fall in output and that prices seemed to be more sluggish and only started to fall significantly below zero, several quarters after changes in GDP. Reassuringly, these results were very similar to those obtained for the US economy, using similar methodologies.

In recent years, researchers have begun to assess monetary policy by the ECB, that is, the single monetary policy in the Euro area after 1999. This has been possible because the common monetary policy in the Euro area is now about 15 years old, therefore, using the latest available data, econometric studies based on time series are now starting to become more robust.

Weber et al. (2009) investigate if there has been a significant change in the overall MTM, by estimating a standard VAR for the Euro area, and by endogenously searching for possible break dates. They report a significant break point around 1996 and some 
evidence for a second one around 1999, concluding that monetary transmission after 1998 is not very different from that of before 1996, but probably very different compared to the interim period of 1996 - 1999, which is indicative of a possible period of adjustment, prior to the Euro. Moreover, they find that the stylized facts of monetary policy transmission remain valid. Boivin, Giannoni and Mojon (2009) report important heterogeneity across countries ${ }^{5}$ in the effect of monetary shocks before the launch of the Euro and conclude that the creation of the Euro has contributed to a greater homogeneity of the transmission mechanism across countries and an overall reduction in the effects of monetary shocks.

In the past couple of years, various authors included the subprime crisis period in their analysis and, in some instances, the more recent sovereign debt crisis. However, these analyses are mostly focused on the effects of the unconventional monetary policy measures that have been taken since. ${ }^{6}$

Tables 1 and 2 present a brief systematic summary of the empirical literature on the MTM, pre, and post-EMU. We identify the period of the analysis, the sample, the methodology, the variables included in the empirical models and then, finally, the main conclusions.

Regarding methodology, the seminal work of Sims (1980) was the precursor for the use of VAR models for the analysis of monetary policy and these models have been, and still are, a widely used framework for the study of the MTM. VAR models provide an empirical method for capturing the dynamic relations between economic variables (time series), without the need to impose rigid identification restrictions. This characteristic of the framework allows for more flexibility and less a priori theorization.

\footnotetext{
${ }^{5}$ The authors constructed a FAVAR, using data from the six largest countries of the Euro area.

${ }^{6}$ See, regarding this point, as an example, Peersman (2011), Giannone et al. (2011) and Giannone et al. (2012).
} 
Table 1 - Related literature overview (pre-EMU sample)

\begin{tabular}{|c|c|c|c|c|c|c|}
\hline & Authors & $\begin{array}{c}\text { Data frequency / } \\
\text { Period }\end{array}$ & Sample & Methodology & Variables & Main conclusions \\
\hline \multirow[t]{4}{*}{ Pre-EMU: } & \begin{tabular}{|l|} 
Guiso, \\
Kashyap, \\
Pannetta, \\
Terlizzese \\
(1999)
\end{tabular} & $\begin{array}{l}\text { The study was } \\
\text { centred on cross- } \\
\text { country } \\
\text { microeconomic } \\
\text { data of June } 1999 .\end{array}$ & $\begin{array}{l}\text { UK, Germany, } \\
\text { Italy, } \\
\text { France, } \\
\text { Spain, } \\
\text { Netherlands, } \\
\text { Belgium }\end{array}$ & $\begin{array}{l}\text { n/a } \\
\text { - the authors } \\
\text { conduct a mainly } \\
\text { descriptive } \\
\text { discussion based on } \\
\text { microeconomic data } \\
\text { from } 7 \text { selected } \\
\text { countries. }\end{array}$ & $\begin{array}{l}13 \text { microeconomic variables, } \\
\text { including: } \\
\text { - employment protection } \\
\text { indicator } \\
\text { - capital output ratio } \\
\text { - fraction of financing that is } \\
\text { short term } \\
\text { - exports outside EU-15 } \\
\text { relative to GDP } \\
\text { - firms' leverage } \\
\text { - household indebtness } \\
\text { - market capitalization } \\
\text { relative to GDP } \\
\text { - average bank size }\end{array}$ & $\begin{array}{l}\text { The authors assess whether what appears } \\
\text { to be large structural differences in the } \\
\text { economic and financial structures of the } \\
\text { various countries can lead to differences } \\
\text { in the transmission mechanism. They find } \\
\text { significant differences across countries in } \\
\text { several indicators that may matter for } \\
\text { monetary transmission, therefore } \\
\text { assymetries may be in place for several } \\
\text { years. However, no definitive conclusions } \\
\text { can be made and several gaps remain to } \\
\text { be filled, namely with relation to how } \\
\text { countries would respond to the same } \\
\text { temporal sequence of monetary policy } \\
\text { shocks, holding fixed the exchange rate } \\
\text { among them. }\end{array}$ \\
\hline & \begin{tabular}{|l|} 
Peersman \\
, Smets \\
$(2003)$
\end{tabular} & $\begin{array}{l}\text { quarterly data } \\
\text { 1980:Q1 - 1998:Q4 } \\
\text { lags=3 }\end{array}$ & $\begin{array}{l}\text { Euro Area } \\
\text { (area wide) }\end{array}$ & \begin{tabular}{|l|} 
VAR \\
- variables in levels \\
- shocks \\
identification: \\
Choleski [the authors \\
test for alternative \\
identification \\
schemes: Sims e Zha \\
(1998); Gali (1992)] \\
- the authors \\
conduct Chow tests \\
for instability at the \\
model after 1990:Q1.
\end{tabular} & $\begin{array}{l}4 \text { endogeneous variables: } \\
\text { - real GDP } \\
\text { - consumer prices } \\
\text { - domestic nominal short- } \\
\text { term interest rate } \\
\text { - real effective exchange rate } \\
3 \text { exogenous variables: } \\
\text { - world commodity price } \\
\text { index } \\
\text { - US real GDP } \\
\text { - US nominal short-term } \\
\text { interest rate }\end{array}$ & $\begin{array}{l}\text { The authors show that the overall } \\
\text { macroeconomic effects of a monetary } \\
\text { policy shock in the euro area are very } \\
\text { similar to those estimated for the US and } \\
\text { are stable over time. } \\
\text { They also examine how various real and } \\
\text { financial variables (GDP components, } \\
\text { monetary variables, asset prices, labour } \\
\text { market variables) respond to an area-wide } \\
\text { impulse. }\end{array}$ \\
\hline & \begin{tabular}{|l} 
Mojon, \\
Peersman \\
$(2003)$
\end{tabular} & $\begin{array}{l}\text { quarterly data } \\
\text { 1980:Q1 - 1998:Q4 } \\
\text { lags=2 or } 3\end{array}$ & \begin{tabular}{|l|} 
Germany; \\
Austria, \\
Belgium and \\
Netherlands; \\
Finland, \\
France, \\
Greece, \\
Ireland, Italy \\
and Spain
\end{tabular} & $\begin{array}{l}\text { VAR } \\
\text { - variables in levels } \\
\text { - three identification } \\
\text { schemes are used, } \\
\text { depending on each } \\
\text { country monetary } \\
\text { integration with } \\
\text { Germany (which is } \\
\text { considered the } \\
\text { nominal anchor of } \\
\text { the ERM). }\end{array}$ & $\begin{array}{l}4 \text { endogeneous variablesl: } \\
\text { - real GDP } \\
\text { - consumer prices } \\
\text { - domestic nominal short- } \\
\text { term interest rate } \\
\text { - real effective exchange rate } \\
3 \text { exogenous variables: } \\
\text { - world commodity price } \\
\text { index } \\
\text { - US real GDP } \\
\text { - US nominal short-term } \\
\text { interest rate }\end{array}$ & $\begin{array}{l}\text { The authors find that the hypotheses that } \\
\text { the effects of monetary policy on GDP and } \\
\text { on prices are broadly similar in the } \\
\text { individual countries of the euro area } \\
\text { cannot be rejected. In every country they } \\
\text { find that an unexpected rise in the short- } \\
\text { term interest rates leads to a decrease in } \\
\text { GDP and a gradual decrease in prices, } \\
\text { however there is some heterogeneity in } \\
\text { the size of the effects. }\end{array}$ \\
\hline & \begin{tabular}{|l|} 
Ciccarelli, \\
Rebucci \\
$(2006)$
\end{tabular} & \begin{tabular}{|l|} 
monthly data \\
1980:M1 - 1998:M12
\end{tabular} & $\begin{array}{l}\text { Germany, } \\
\text { France, } \\
\text { Italy, } \\
\text { Spain }\end{array}$ & $\begin{array}{l}\text { VAR } \\
\text { (bayesian } \\
\text { estimation) } \\
\text { - two steps: } \\
\text { 1) measuring } \\
\text { monetary policy } \\
\text { through a time- } \\
\text { varying SVAR; } \\
\text { 2) modeling the } \\
\text { transmission } \\
\text { mechanism through } \\
\text { a time-varying VAR. }\end{array}$ & $\begin{array}{l}\text { 1) SVAR: } \\
\text { endogenous variables: } \\
\text { - short term interest rates of } \\
\text { the } 4 \text { countries } \\
\text { exogeneous variables: } \\
\text { - (inflation - target inflation) } \\
\text { - (output - target output) } \\
\text { - (nominal exchange rate - } \\
\text { target nominal exchange } \\
\text { rate) } \\
\text { - } \Delta \text { index of commodities } \\
\text { price; - } \Delta M 3 ; \\
\text { - US short term interest rate } \\
\text { 2) VAR: } \\
\text { endogenous variables: } \\
\text { - nominal exchange rate of } \\
\text { ECU } \\
\text { - germany interest rate } \\
\text { - spread over Germany } \\
\text { money market interest rate } \\
\text { exogeneous variables: } \\
\text { - commodity prices; } \\
\text { - US output index }\end{array}$ & $\begin{array}{l}\text { The authors study, for the pre-EMU period, } \\
\text { the transmission mechanism of a common, } \\
\text { homokedastic monetary policy shock, } \\
\text { identified as an innovation to the reaction } \\
\text { function of the Bundesbank, in Germany, } \\
\text { France, Italy and Spain. They find that the } \\
\text { long-run cumulative impact on output of a } \\
\text { common, homoskedastic monetary policy } \\
\text { shock has decreased in all countries after } \\
\text { 1991. At the same time, cross-country } \\
\text { differences in the effects of this shock } \\
\text { have not decreased over time. The authors } \\
\text { conclude that the transmission mechanism } \\
\text { of European monetary policy is probably } \\
\text { changing over time, albeit slowly and in all } \\
\text { countries at the same time. }\end{array}$ \\
\hline
\end{tabular}


Table 2 - Related literature overview (including post-EMU sample)

\begin{tabular}{|c|c|c|c|c|c|c|}
\hline & Authors & \begin{tabular}{|c|}
$\begin{array}{c}\text { Data frequency / } \\
\text { Period }\end{array}$ \\
\end{tabular} & Sample & Methodology & Variables & Main conclusions \\
\hline $\begin{array}{l}\text { Post- } \\
\text { EMU: }\end{array}$ & $\begin{array}{l}\text { Weber, } \\
\text { Gerke, } \\
\text { Worms } \\
(2009)\end{array}$ & $\begin{array}{l}\text { quarterly data } \\
\text { 1980:Q1 - 2006:Q4 } \\
\text { lags=2 }\end{array}$ & \begin{tabular}{|l} 
Euro Area \\
(area wide)
\end{tabular} & $\begin{array}{l}\text { VAR } \\
\text { - variables in levels } \\
\text { - shocks } \\
\text { identification: } \\
\text { Choleski; sign } \\
\text { restriction [Uhlig } \\
\text { (2005)]; } \\
\text { - breakpoint tests: } \\
\text { Chow tests; } \\
\text { Ploberger, Kramer, } \\
\text { Kontrus fluctuation } \\
\text { test. }\end{array}$ & $\begin{array}{l}4 \text { endogeneous variables: } \\
\text { - real GDP } \\
\text { - GDP deflator } \\
\text { - indicator of real housing } \\
\text { wealth } \\
\text { - domestic nominal interest } \\
\text { rate (3M) } \\
\text { (inclusion of long term } \\
\text { interest rate and money does } \\
\text { not improve model) } \\
2 \text { exogenous variables: } \\
\text { - non-oil commodity price } \\
\text { index } \\
\text { - US short term interest rate }\end{array}$ & $\begin{array}{l}\text { The authors approach is to identify break dates in } \\
\text { the Monetary Transmission Mechanism (MTM) of } \\
\text { the Euro Area, independent of specific causes and } \\
\text { then checking whether MTM as a whole has } \\
\text { changed. The authors find two break points, one in } \\
\text { 1996, another in 1999. The MTM in 1980-1996 is } \\
\text { similar to the one in } 1999 \text { - 2006. There seems to } \\
\text { have been an atypical interim period in } 1996 \text { - } 1999 . \\
\text { The comparisons on MTM are made first by visually } \\
\text { comparing the Impulse Response Functions and } \\
\text { then by estimating an extended VAR with period } \\
\text { dummy and conducting tests for the coefficients of } \\
\text { the dummys. }\end{array}$ \\
\hline \multirow[t]{3}{*}{$\begin{array}{r}\text { after } \\
\text { subprime: }\end{array}$} & $\begin{array}{l}\text { Cecioni, } \\
\text { Neri } \\
(2011)\end{array}$ & \begin{tabular}{|l|} 
monthly data: \\
Pre-EMU: \\
1994:M1 - 1998:M12 \\
Post-EMU: \\
1999:M1 - 2007:M7 \\
and \\
1999:M1 - 2009: M9 \\
(post EMU sub- \\
samples to test for \\
subprime effects ) \\
lags=4 \\
quarterly data (to \\
assess robustness \\
of results): \\
1989:Q1 - 2009:Q2 \\
lags=3
\end{tabular} & $\begin{array}{l}\text { Euro Area } \\
\text { (area wide) }\end{array}$ & $\begin{array}{l}\text { SVAR and DGSE } \\
\text { (bayesian } \\
\text { estimation) } \\
\text { - variables in levels } \\
\text { - shocks } \\
\text { identification: } \\
\text { recursive (Choleski); } \\
\text { Sims e Zha (1999); } \\
\text { sign restrictions } \\
\text { [Uhlig (2005)]. }\end{array}$ & \begin{tabular}{|l|} 
SVAR: \\
6 endogeneous variables: \\
(monthly) \\
- industrial production \\
- HICP \\
- EONIA; \\
- M2 \\
- commodities prices \\
- nominal effective exchange \\
rate \\
6 endogeneous variables: \\
(quarterly) \\
- real GDP \\
- GDP deflator \\
- 1 month interest rate; \\
- M2 \\
- commodities prices \\
- nominal effective exchange \\
rate
\end{tabular} & $\begin{array}{l}\text { The autors do not search for structural breaks in the } \\
\text { data, they assume that such a break may have } \\
\text { ocurred in 1999:M1 with the creation of the EMU. } \\
\text { They find: } \\
\text { - SVAR: The effects of a monetary policy shock on } \\
\text { output and prices have not significantly changed } \\
\text { over time. Also there are no significant differences } \\
\text { before and after the burst of the subprime turmoil. } \\
\text { The authors claim that this cannot be the final word } \\
\text { on the evolution of the MTM as changes in the } \\
\text { conduct of monetary policy and the structure of the } \\
\text { economy may have offset each other giving rise to } \\
\text { similar responses of output and inflation to } \\
\text { monetary policy shocks between the two periods. } \\
\text { - DGSE: monetary policy has become more } \\
\text { effective in stabilizing the economy as the result of } \\
\text { a decrease in the degree of nominal rigidities and a } \\
\text { shift in monetary policy towards inflation } \\
\text { stabilization. }\end{array}$ \\
\hline & \begin{tabular}{|l|} 
Peersman \\
$(2011)$
\end{tabular} & $\begin{array}{l}\text { monthly data } \\
\text { 1999:M1 - 2009:M2 } \\
\text { lags=4 }\end{array}$ & $\begin{array}{l}\text { Euro Area } \\
\text { (area wide) }\end{array}$ & $\begin{array}{l}\text { SVAR } \\
\text { (bayesian } \\
\text { estimation) } \\
\text { - variables in levels } \\
\text { - shocks } \\
\text { identification: zero } \\
\text { and sign restrictions } \\
\text { - breakpoint tests to } \\
\text { test for stability: } \\
\text { Quandt-Andrews, } \\
\text { CUSUM, Chow. }\end{array}$ & $\begin{array}{l}6 \text { endogeneous variables: } \\
\text { - industrial production } \\
\text { - HICP } \\
\text { - volume of bank credit } \\
\text { - monetary base } \\
\text { - level of interest rate on } \\
\text { credit } \\
\text { - level of the monetary policy } \\
\text { rate }\end{array}$ & $\begin{array}{l}\text { Macroeconomic effects of unconventional } \\
\text { monetary policies (characterized by increasing the } \\
\text { size of balance sheet or the monetary base) are } \\
\text { similar to the effects obtained through innovations } \\
\text { of interest rates. However, the transmission } \\
\text { mechanism is different in terms of timings, } \\
\text { interest rate spreads and credit multipliers. }\end{array}$ \\
\hline & \begin{tabular}{|l} 
Giannone, \\
Lenza, \\
Phil, \\
Reichlin \\
(2011)
\end{tabular} & \begin{tabular}{|l|} 
monthly data \\
.1991:M1 - 2008:M8 \\
(pre-subprime crisis \\
to estimate model \\
and study stilized \\
facts) \\
1999:M1 - 2010:M3 \\
(based on the \\
previous time \\
sample, the \\
authors estimate \\
previsions for this \\
second sub- \\
sample) \\
lags=13
\end{tabular} & $\begin{array}{l}\text { Euro Area } \\
\text { (area wide) }\end{array}$ & $\begin{array}{l}\text { VAR } \\
\text { (bayesian } \\
\text { estimation) } \\
\text { - variables in levels. }\end{array}$ & $\begin{array}{l}39 \text { variables, including: } \\
\text { - macroeconomic, financial, } \\
\text { monetary and credit variables } \\
\text { plus a set of variables from } \\
\text { the US to capture } \\
\text { international linkages. } \\
\text { (for more detail please see } \\
\text { table 1, pp. } 6 \text { of Giannone, } \\
\text { Lenza, Reichlin (2012)) }\end{array}$ & $\begin{array}{l}\text { During the financial crisis } 2007-2010 \text { the ECB not } \\
\text { only cut interest rates significantly but also } \\
\text { introduced a package of non-standard monetary } \\
\text { policy measures, intended to complement } \\
\text { standard interest rate decisions, and not substitute } \\
\text { them, with the aim to insure the effectiveness of } \\
\text { the monetary transmission mechanism. The } \\
\text { authors conclude that non-standard monetary } \\
\text { policy measures introduced by the ECB following } \\
\text { Lehman's demise were successful in insulating, at } \\
\text { least in part, the liquidity and credit conditions } \\
\text { facing households and firms from the breakdown } \\
\text { of financial intermediation seen in the interbank } \\
\text { money market in late } 2008 \text {, thus the stylised facts } \\
\text { of the monetary transmission mechanism were } \\
\text { observed. }\end{array}$ \\
\hline
\end{tabular}




\subsection{Fiscal policy, monetary policy and financial instability}

The effects of monetary policy on macroeconomic aggregates have been studied broadly, mainly by using VAR frameworks, or the New Keynesian DSGE models and some stylized facts have been identified as we have mentioned previously. Particularly for the Euro area, researchers have then turned their focus to the impact of the EMU on those stylized facts, and, more recently, on the functioning of the different transmission channels during the subprime and the sovereign debt crisis, as well as the effects of the unconventional monetary policy response to the crises.

Conversely, when it comes to the effects of fiscal policy on macroeconomic aggregates, there are no stylized facts, i.e., there are no facts which are broadly agreed upon. The difficulties start on the basics: how to distinguish between a change in revenues and expenditures, caused by automatic stabilizers and a deliberate fiscal policy change. Afonso et al. (2011) present a comprehensive review of fiscal policy VARrelated literature and they point out the different results that often arise when different identification schemes are used and also in cross-country samples.

For instance, Afonso et al. (2011) use a Threshold VAR to study the effects of fiscal policy in high financial stress regimes and low financial stress regimes. They find that the response of economic growth to fiscal shocks is generally positive in both financial stress regimes and that financial stress has a negative effect on output growth and that it increases the government debt-to-GDP ratio. Their country sample ${ }^{7}$ also indicates that the initial conditions, such as, the existence of financial stress, diverse levels of government indebtedness and implicit monetary policy, are relevant in determining the nonlinearities that were found regarding the effects of a fiscal shock on economic activity.

Interactions between financial system stress and monetary policy are also relevant. Stress in the banking sector, stock markets and exchange rate markets may play important roles in the transmission of monetary policy shocks. ${ }^{8}$ For example, Baxa et al.

\footnotetext{
${ }^{7}$ They estimate a TVAR for the US, UK, Germany and Italy.

${ }^{8}$ In the case of the exchange rate, they may be more relevant for open economies, than for a large and relatively closed economy, such as the Euro area.
} 
(2013) conclude that central banks, when faced with high financial stress, often alter the course of monetary policy, mainly by lowering interest rates and also that the size of the response varies overtime, as well as across countries. ${ }^{9}$ They also report some crosscountry heterogeneity with regard to the effects of specific types of financial stress.

\section{Econometric framework}

To analyze the effects of a monetary policy shock in the Euro area, we use a VAR model with the following representation:

$$
\text { [1] } \quad Z_{t}=A(L) Z_{t-1}+\mu_{t}
$$

where $Z_{t}$ is the vector of endogenous variables, and $u_{t}$ is the vector of serially uncorrelated disturbances that have a zero mean and a time invariant covariance matrix. $A(L)$ denotes a polynomial matrix in the lag operator. We also include a constant in the model.

The vector of endogenous variables in our benchmark model consists of six Euro area variables: real GDP growth $\left(y_{t}\right)$, inflation $\left(p_{t}\right)$, annual change in the debt-to-GDP ratio $\left(f_{t}\right)$, long-term nominal interest rate $\left(l_{t}\right)$, short-term nominal interest rate $\left(i_{t}\right)$ and a financial stress indicator $\left(s_{t}\right)$ :

[2] $\quad Z_{t}^{\prime}=\left[\begin{array}{llllll}y_{t} & p_{t} & f_{t} & l_{t} & i_{t} & s_{t}\end{array}\right]$.

The inclusion of a debt sustainability indicator (proxied by the debt-to-GDP ratio) and a measure of financial stress, although not common in the monetary policy VAR related literature, will hopefully allow us to incorporate in the dynamics of our model two variables that historically, and possibly more markedly in (recent) times of economic and financial distress, may influence the Monetary Transmission Mechanism. $^{10}$

We identify the monetary policy shocks by assuming a recursive (Choleski) structure. The variables are ordered as in [2], which reflects some assumptions

\footnotetext{
${ }^{9}$ Their sample includes the US, UK, Australia, Canada and Sweden.

${ }^{10}$ Regarding this, see, as an example, our literature reviews on Afonso et al. (2011) and Baxa et al. (2013).
} 
regarding the links between the economic variables. Specifically, we assume that the monetary policy shocks (i.e., the changes in short-term nominal interest rate $-i_{t}$ ) do not have a contemporaneous impact on output, prices, debt-to-GDP ratio and long term interest rates, but that they may contemporaneously affect the financial stress indicator. On the other hand, the policy interest rate does not respond to contemporaneous changes in the financial stress indicator. The ordering of the fiscal variable before output, follows Afonso et al. (2011), and is justified by the need to identify the effects of automatic stabilizers on the economy. The financial stress indicator is ordered last, which implies that it reacts contemporaneously to all variables in the system.

The lag length of the endogenous variables, $Z_{t}$, is an important aspect of the estimation procedure, as, if the lag length is too small, then the model may be wrongly specified and if it is too long, then degrees of freedom are being lost. The usual lag length selection criteria are presented in appendix A.3. The tests results indicate one lag for the Schwarz information criteria (SC) and two lags for Akaike (AIC) and HannanQuinn (HQ) information criteria. The Akaike criteria may overestimate the lags, but the SC and HQ are consistent for small samples (Lutkepohl (2005)). We opt for one lag, mainly because the limited number of observations in the pre and post-EMU subsamples could impair the estimation of a six variable VAR, should more lags be considered.

\section{Empirical analysis}

\subsection{The data and variables}

We estimate the VAR model using quarterly data from Q1 1987 to Q4 2011. The source for the Euro area wide macroeconomic time-series was the $12^{\text {th }}$ update of the Area-Wide Model (AWM) database ${ }^{11}$, except for the case of the government debt for the Euro area, which was retrieved from the Quarterly Fiscal database for the Euro

\footnotetext{
${ }^{11}$ For a description of the model and dataset, see Fagan et al. (2001) and the respective statistical Appendix.
} 
area. $^{12}$ The financial stress index that we use for the Euro area, is the Composite Indicator of Systemic Stress (CISS), proposed by Halló et al. (2012) ${ }^{13}$, and the data was made available by the ECB. The time sample is limited, due to data availability. In particular, the CISS time series only starts in 1987 and the data from the latest available update of the AWM database stops in Q4 2011.

For real GDP and the GDP deflator, we use the annual growth rates of the logs. For the debt-to-GDP ratio we use the annual change in the ratio. These transformations allow us to sidestep the known non-stationary characteristics of the original levels variables. Real GDP, GDP deflator and debt-to-GDP ratio are all seasonally adjusted. The monetary policy instrument is a three month nominal interest rate, as in Fagan et al. (2001). For CISS we computed the quarterly averages of weekly values. ${ }^{14}$

\subsection{Overview of macroeconomic, monetary, fiscal and financial developments ${ }^{15}$}

The average year-on-year growth rate of real GDP for the Euro in our sample was $1.9 \%$. During these 25 years there were two very marked recessions, the first one was in 1993 and the second and deeper recession was in 2008-2009. Furthermore, smaller growth rates were observed in 2002-2003 and after the second Quarter of 2011.

Regarding the annual change in the GDP deflator (our proxy for inflation), and long and short term interest rates, there has been a change in the levels of these variables, in the sense that, during the $90 \mathrm{~s}$, there was a decrease in the values from the considerable high levels observed in the end of the 1980s to more or less stabilized lower levels from 1998 onwards.

\footnotetext{
${ }^{12}$ For a description of the database, please see Paredes et al. (2009). We use Euro Area general government debt, and then calculate the debt-to-GDP ratio, using the GDP provided in the AWM database. The resulting series has a very good match with the Eurostat debt-to-GDP ratio series for the Euro area, available only with data after Q1 2000.

${ }^{13}$ The CISS is an indicator of contemporaneous stress in the financial system, proposed by Halló et al. (2012). Its main goal is to "measure the (...) current level of frictions, stresses and strains (or the absence of these) in the financial system and to condense that state of financial instability into a single statistic" (idem). It is a composite indicator, focused on the systemic dimension of financial stress, and comprises the five most important segments of an economy's financial system: bank and non-bank financial intermediaries, money markets, securities (equities and bonds) markets and foreign exchange markets. For more details on the construction of the CISS, please refer to Halló et al. (ibidem).

${ }^{14}$ In Appendix A.1 we present all the data and sources, in a systematic manner.

${ }^{15}$ In Appendix A.2 we present the graphical representation of the time series of our variables.
} 
The debt-to-GDP ratio for the Euro area has increase at a steady pace from just below $60 \%$ in 1987, to around $75 \%$ in 1996. From 1996 to 2008, the ratio has declined somewhat, attaining a level of $67 \%$ in 2008 . After 2008, and related notably to the government's response to the subprime crisis and also to the need to capitalize the banking sector, there was a very sharp increase in the debt-to-GDP ratio, which at the end of 2010 had already climbed to $86 \%$ of GDP. During 2011, the ratio continued to increase, albeit at a slower pace, closing the year at $88 \%$.

Finally, concerning the Composite Indicator of Systemic Stress - our financial stress variable - we can observe a prolonged period of very high stress in the Euro area from Q3 2007 until the end of our sample in Q4 2011 (with slight improvements in Q3 2010 and Q4 2010). The very high financial stress in this period is, on the one hand, due to the subprime crisis, whose first signs appeared during 2007 - namely with the decision by BNP Paribas on the $9^{\text {th }}$ of August, 2007, to stop the bail-out of three funds by BNP Paribas that were affected by the subprime problems - and was compounded by the failure of Lehman Brothers on the $15^{\text {th }}$ of September, 2008, resulting in the highest historical levels of CISS in Q4 2008 and Q1 2009. On the other hand, from the end of 2009 onwards, the high levels of financial stress are mainly justified by the sovereign debt crises in Europe that followed the subprime crises. The first signs appeared on the yields of Greek sovereign bonds, whose rise led to the joint financial assistance program to Greece by the IMF, the European Commission and the ECB (the "Troika"), in May 2010. Afterwards, the financial assistance program to Ireland also occurred in November, 2010, and another one for Portugal in May, 2011. Apart from the very high periods of stress after 2007, the rest of our sample have some other episodes of increased financial stress, albeit at comparatively lower levels, including the European Exchange Rate Mechanism crisis in 1992, the Russian crisis in 1998-1999, and a period of increased stress in 2001, following the events of the $9^{\text {th }}$ of September. 


\subsection{Empirical results}

We are interested in investigating whether there have been changes in the MTM, in association with the adoption of the Euro and also in the interactions between monetary and fiscal policy. To that end, we consider two balanced sub-samples: the first subsample refers to the years prior to the adoption of the Euro, and runs from Q1 1987 to Q4 1998; the second sub-sample includes the post-Euro adoption years - Q1 1999 to Q4 2011. The aim is to inspect the respective impulse response functions (IRFs) and to detect any differences that may exist between them. ${ }^{16}$

Furthermore, we also explore the relevance of additional sub-samples, namely, a subprime and a sovereign debt crisis sub-sample. In order to do so, we exclude from the post-EMU sub-sample the final years - which correspond to the periods of these two crises.

Our VAR model includes two macroeconomic policy variables - interest rate and debt-to-GDP ratio - and a financial stress variable. Therefore, it can be used to study the interactions of fiscal and monetary policy, on one hand, and of these two macro variables with financial stress, on the other hand. It is possible to study these interactions in our framework by basically analysing the impact of monetary shocks on the fiscal variable, as well as the impact of fiscal shocks on the interest rate and also the impact of financial stress on both variables (as well as on all the other non-policy related variables in our VAR).

\subsubsection{The effects of interest rates shocks}

The complete set of responses of the variables to the (negative) monetary shock, for all sub-samples, is shown in appendix A.4. The solid line depicts the median response estimate and the dashed lines show the two-standard error confidence intervals. For all sub-samples considered, the one-standard deviation monetary policy shock is estimated

\footnotetext{
${ }^{16}$ We implicitly assume that the adoption of the Euro in Q1 1999 may be a cause for a structural break in the monetary transmission mechanism. Another approach would be to test the data for the existence of such a break, as done by Weber et al. (2009), but our short time-sample limits the robustness of econometric testing for structural breaks.
} 
to be around 30 basis points, which is in line with the estimate obtained by Peersman and Smets (2003).

Comparing the pre-EMU and post-EMU sub-samples, we can observe a stronger response of the main macro-economic variables to a negative interest rate shock (i.e., a temporary increase in the short-term interest rate) in the post-EMU sub-sample. In particular, the output growth reacts more negatively in the first 8 to 10 Quarters, and then the recuperation of output growth occurs at a faster pace. Although there are differences in the amplitude of output growth response, the time frames over which these responses develop does not seem to differ significantly between the two subsamples - whilst in the pre-EMU sub-sample, the output growth turns positive after around 14 Quarters and in the post-EMU sub-sample, such recovery occurs after 12 Quarters.

With regards to inflation, there seems to be a somewhat bigger price-puzzle ${ }^{17}$ in the post-EMU sub-sample, than in the pre-EMU sub-sample. The negative response of inflation to an increase in interest rate seems to be of a similar scale, although in the preEMU period, the response is somewhat more prolonged in time.

Concerning the response of the fiscal variable, we observe a much higher increase in the debt-to-GDP ratio after a negative interest rate shock in the post-EMU sub-sample, than in the pre-EMU sub-sample. In fact, the increase in the annual change of the debtto-GDP ratio in the second sub-sample more than doubles that of the first sub-sample. The same pattern holds for the financial stress response - a negative monetary policy shock has a much higher impact on the financial stress variable in the post-EMU subsample, than in the pre-EMU sub-sample.

Overall, the changes in the responses of our VAR variables in the post-EMU subsample are more significant for the fiscal and financial stress variables, than for output growth and inflation. These changes may be a consequence of a higher degree of synchronization of the Euro area countries' economies after the adoption of the Euro.

\footnotetext{
${ }^{17}$ A price-puzzle is a price increase following a tightening of interest rates, which is a widespread feature in VAR literature.
} 
However, if we exclude the Quarters after the beginning of the subprime crises from the post-EMU sub-sample, i.e., if our post-EMU sub-sample stops at Q2 2007, then IRFs are of a much smaller magnitude ${ }^{18}$ and, also, there is a very considerable pricepuzzle. As Peersman (2011) concluded, the policy response to the recession after the subprime crises seems to have improved the identification of conventional monetary policy shocks. In our paper we can further corroborate that this may have been the case, because our sub-sample which excludes the sovereign debt crisis, yields results that are much similar to the full sample results. Therefore, it was the subprime crises' period, and not the sovereign debt crises' period that contributed to improving the identification of conventional monetary policy shocks.

\subsubsection{The effects of fiscal shocks}

The complete set of responses of the variables to the positive fiscal shock, for all sub-samples, is shown in Appendix A.5. If we compare the period of Q1 1987 - Q4 1998 to the period of Q1 1999-Q4 2011, the changes in the IRFs of our variables to a fiscal shock are substantial, not only in magnitude, but also in the directions of the responses. For instance, the response of output growth to a positive fiscal shock in the second sub-sample is negative in the first few quarters, whilst such an answer is positive in the pre-EMU sub-sample.

These changes may be related to the Governments' answer to the subprime recession - after the subprime crises there was a steep increase in governments' debt-to-GDP ratio and this increase was accompanied by a deep recession. This idea is supported by the following: if we look at the estimates of the one-standard deviation fiscal policy shock, we conclude that such a shock was estimated to be around 0.3 percentage points (p.p.) in the pre-EMU period, but its estimate rose to more than 0.5 p.p. in the post-EMU subsample. However, if we exclude the subprime period (and the sovereign debt crises

\footnotetext{
${ }^{18}$ Boivin et al. (2009) also find an overall reduction in the effects of monetary shocks after 1999, using a sample that does not include the subprime crises (their sample stops in Q3 2007). They conclude that "their model predicts that by removing an exchange-rate risk through the monetary union, and by having a central bank more decisively focused on inflation and output stabilization, the impact of monetary disturbances on measures of economic activity has been reduced, as observed in the data".
} 
period) - i.e., if we consider the Q11999- Q2 2007 sub-sample - the estimate of a onestandard deviation fiscal policy shock comes down to just over 0.2 p.p.. The lower-thanaverage real GDP growth, and higher-than-average annual increase in debt-to-GDP ratio that characterise the sovereign debt crises, may also be importantly related to the change in direction of the output growth response to a fiscal shock.

In the pre-EMU sub-sample, the long-term interest rate responds with a steady increase to a positive fiscal shock, whilst the short-term interest rate responds with a slight decrease in the first few Quarters, followed by a prolonged increase. In the posEMU sub-sample, both the short-term and long-term interest rate responses are negative in the first few Quarters, and then turn to slightly positive territory after about 15 Quarters, albeit the scale of the fall, and posterior rise, of short term interest rate is comparatively higher. Therefore, a positive fiscal shock seems to be followed by a steepening of the yield curve in the short run, for both sub-samples.

\subsubsection{The effects of financial stress shocks}

The complete set of responses of the variables to financial stress shock, for all subsamples, is shown in Appendix A.6. As expected, the shocks are considerably higher in the post-EMU sub-sample, if we include the subprime and the sovereign debt crisis period. In the full post-EMU sub-sample, the one-standard deviation financial stress shock is estimated at around 45 points, whilst for the pre-EMU and post-EMU except subprime sub-samples, the estimates are similar, at around 30 points.

Concerning the IRFs to a financial stress shock, by construction, there is no contemporaneous impact on the variables of our model. Comparing the pre-EMU subsample with the Q1 1999-Q2 2007 responses, there seems to be a slight decrease in the magnitude of the responses of the macroeconomic variables in our model to a financial stress shock, but the pattern of such responses remains the same - small temporary increases in output growth and small temporary decrease in inflation, followed also by a temporary increase. 
On the contrary, if we include the period of the subprime crises in the post-EMU sub-sample (i.e., if we consider the period Q1 1999- Q4 2009), then there has been a clear change in the magnitude and pattern of responses, with output growth responding in a strong and negative fashion to the shock, and debt-to-GDP responding with a strong increase in its annual change. Furthermore, including the sovereign debt crises period (i.e., considering the whole post-EMU period - Q1 1999 to Q4 2011) increases the negative response of output growth to the financial stress shock. Lastly, there is a positive response of the long term interest rate to a financial stress shock in all of the post-EMU sub-samples, which did not exist in the pre-EMU sub-sample.

\subsection{Robustness check: an alternative pre-EMU sub-sample}

Weber et al. (2009) found that there may have been a significant break point in the monetary mechanism period in the Euro area around 1996 and also some evidence for a second one around 1999, suggestive of an interim period from Q2 1996 to Q4 1998 of adjustment, prior to the Euro. Following that conclusion we estimate a VAR from Q1 1981 to Q1 1996 and also the respective IRFs and then compare them with the postEMU sub-samples.

The bulk of our conclusions remain valid. However, there is an interesting insight regarding the response of output growth to a fiscal shock. As it turns out, the alternative pre-EMU sub-sample, yields a decrease in output growth following a fiscal shock (albeit a small and temporary decrease), whilst the original pre-EMU sub-sample yielded a considerable positive and lasting response of real GDP growth to a fiscal shock. Yet the conclusion still holds - that the characteristics of the subprime and sovereign debt crises were the main drivers behind the changes in the responses of macro variables to a fiscal shock. 


\section{Conclusions}

The adoption of the Euro and of a single monetary policy might have contributed to changing the monetary transmission mechanism and the interactions between monetary policy, fiscal policy and financial stress in the Euro area.

Our results indicate that the stylised facts of monetary transmission remain valid, but the response of output and, especially, of the fiscal and financial stress variables to an increase in the short term interest rate, seems to be stronger in the post-EMU period. These changes may be a consequence of a higher degree of synchronization of the Euro area countries' economies after the adoption of the Euro. However, if we exclude the subprime crises from the post-EMU period, then the sizes of the responses are much smaller. Our results support Peersman's (2011) conclusion that policy response to the subprime recession seems to have improved the identification of conventional monetary policy shocks.

In addition, regarding fiscal and financial stress shocks, the inclusion in our postEMU sub-sample of the subprime and sovereign debt crises yields, changes in the scale, and also in the patterns of the responses of the main variables of our model. For instance, there is a very strong increase in the debt-to GDP ratio following a financial stress shock in the post-EMU period, whilst such a response was negative in the preEMU period. Another important feature is the small magnitude of the IRFs of the postEMU period, when we exclude the subprime and sovereign debt crises.

Overall, we find that the subprime and sovereign debt crises period has contributed markedly to the post-EMU impulse response functions and, if we exclude that period of financial turbulence from the post-EMU sample, then the responses of our VAR variables to monetary, fiscal and financial stress shocks are of a remarkably small magnitude. 


\section{References}

Afonso, A., J. Baxa and M. Slavik (2011), Fiscal developments and financial stress: a threshold VAR analysis, ECB Working Paper No. 1319.

Angeloni, I., A. Kashyap and B. Mojon (eds.) (2003), Monetary Transmission in the Euro Area, Cambridge University Press.

Angeloni, I., A. Kashyap, B. Mojon and D. Terlizzese (2003), Monetary Transmission in the Euro Area: were do we stand?, in Monetary policy transmission in the Euro area, I. Angeloni, A. Kashyap and B. Mojon (eds), Cambridge University Press, Chapter 24.

Apel, E. (1998), European Monetary Integration 1958 - 2002, Routledge.

Baxa, J., R Horváth and B. Vasícek (2013), Time-varying monetary-policy rules and financial stress: does financial instability matter for monetary policy?, Journal of Financial Stability, Issue 9.

Boivin, J., M. P. Giannoni and B. Mojon (2009), How has the Euro changed the monetary transmission?, in NBER Macroeconomics Annual 2008, Vol. 23, National Bureau of Economic Research.

Boivin, J., M. Kiley and F. Mishkin (2010), How has the transmission mechanism evolved over time?, NBER Working paper No. 15879.

Ciccarelli, M. and A. Rebucci (2006), Has the transmission mechanism of European monetary policy changed in the run-up to EMU?, European Economic Review, Vol. 50, No. 3.

Cecioni, M. and S. Neri (2011), The monetary transmission mechanism in the Euro area: has it changed and why?, Banca d'Italia Working Paper No. 808.

Fagan, G., J. Henry and R. Mestre, (2001), An area wide (AWM) model for the Euro area, Working Paper 42, ECB Working Paper No. 42.

Gali, J. (1992), How well does the IS-LM model fit postwar US data?, Quarterly Journal of Economics, May, Vol. 107, No. 2

Giannone, D., M. Lenza, H. Phill and L. Reichlin (2011), Non-standard monetary policy measures and monetary developments, ECB Working Paper No. 1290.

Giannone, D., M. Lenza and L. Reichlin (2012), Money, Credit, Monetary Policy and the Busines Cycle in the Euro Area, ECARES Working Paper.

Guiso, L., A. Kashyap, F. Panetta and D. Terlizzese (1999), Will a Common European Monetary Policy Have Asymmetric Effects?, Economic Perspectives 4, Federal Reserve Bank of Chicago. 
Halló, D., M. Kremer and M. L. Duca (2012), CISS - A Composite Indicator of Systemic Stress in the Financial System, ECB Working Paper No. 1426.

Lutkeppohl, H. (2005), New Introduction to Multiple Time Series Analysis, Springer.

Lutkeppohl, H. (2011), Vector Autoregressive Models, Economics Working Papers ECO 2011/30, European University Institute.

Mojon, B. and G. Peersman (2003), A VAR description of the effects of monetary policy in the individual countries of the Euro area, in Monetary policy transmission in the Euro area, I. Angeloni, A. Kashyap and B. Mojon (eds), Cambridge University Press, Chapter 3.

Paredes, J., D. Pedregal and P. Jávier (2009), A Quarterly Fiscal database for the Euro Area based on intra-annual fiscal information, ECB Working Paper No. 1132.

Peersman, G. and F. Smets (2003), The monetary transmission mechanism in the Euro area: more evidence from VAR analysis, in Monetary policy transmission in the Euro area, I. Angeloni, A. Kashyap and B. Mojon (eds), Cambridge University Press, Chapter 2.

Peersman, G. (2004), The transmission of monetary policy in the Euro Area: are the effects different across countries?, Oxford Bulletin of Economics and Statistics, Vol. 66, No.3.

Peersman, G. (2011), Macroeconomic effects of unconventional monetary policy in the Euro Area, ECB Working Paper No. 1397.

Sims, C. (1980), Macroeconomics and Reality, Econometrica, Vol. 48, No. 1

Sims, C., J. Stock and M. Watson (1990), Inference in Linear Time Series Models With Some Unit Roots, Econometrica, Vol. 58, No. 1.

Sims, C. and T. Zha (1998), Bayesian methods for dynamic multivariate models, International Economic Review, Vol. 39, No. 4.

Sims, C. and T. Zha (1999), Error bands for impulse responses, Econometrica, Vol. 67, No. 5.

Uhlig, H. (2005), What are the effects of monetary policy on output? Results from an agnostic identification procedure, Journal of Monetary Economics, Vol. 52.

Ungerer, H. (1997), A Concise History of European Monetary Integration - from EPU to EMU, Praeger.

Weber, A., R. Gerke and A. Worms (2009), Has the monetary transmission process in the Euro Area changed? Evidence based on VAR estimates, BIS Working Paper No. 276. 


\section{Appendix}

\section{A. 1 - Data description and sources}

Variables in the VAR model:

$y_{t}$ GDP, annual growth rate of the log of the real GDP (Y) used: $y_{t}=\log \left(Y_{t}\right)-\log \left(Y_{t-4}\right)$.

$p_{t}$ Price level (P), annual growth rate of logs used: $p_{t}=\log (P t)-\log (P t-4)$.

$l_{t}$ Long term interest rate.

$i_{t}$ Short-term interest rate.

$f_{t}$ Annual change in the debt to GDP ratio: $f t=F_{t}-F_{t-4}$.

$s_{t}$ Financial stress index (CISS), quarterly averages of weekly values.

Sources:

\begin{tabular}{|c|c|c|c|c|c|c|}
\hline \multicolumn{2}{|r|}{ Variables } & Data Sources & Periodicidade & $\begin{array}{c}\text { Time sample } \\
\text { availabitlity }\end{array}$ & $\begin{array}{l}\text { Seasonally } \\
\text { adjusted? }\end{array}$ & Series ID \\
\hline \multicolumn{7}{|c|}{ Euro Zone } \\
\hline$Y_{t}$ & GDP (real) & $\begin{array}{l}\text { Area Wide Model Database } \\
\text { - 12th update }\end{array}$ & quarterly & 1980Q1-2011Q4 & Yes & YER \\
\hline$P_{t}$ & GDP deflator & $\begin{array}{l}\text { Area Wide Model Database } \\
\text { - 12th update }\end{array}$ & quarterly & 1980Q1-2011Q4 & Yes & YED \\
\hline$l_{t}$ & Long term interest rate (nominal) & $\begin{array}{l}\text { Area Wide Model Database } \\
\text { - 12th update }\end{array}$ & quarterly & 1980Q1-2011Q4 & & LTN \\
\hline$i_{t}$ & Short term interest rate (nominal) & $\begin{array}{l}\text { Area Wide Model Database } \\
\text { - 12th update }\end{array}$ & quarterly & 1980Q1-2011Q4 & & STN \\
\hline $\boldsymbol{F}_{t}$ & Debt/GDP & $\begin{array}{l}\text { Quarterly Fiscal Database - } \\
\text { ECB }\end{array}$ & quarterly & 1980Q4-2012Q4 & Yes & MAL \\
\hline$S_{t}$ & $\begin{array}{l}\text { Composite Indicator of Systemic } \\
\text { Stress }\end{array}$ & ECB & weekly & $1987-2013$ & & CISS \\
\hline
\end{tabular}

\section{A. 2 - Data on the variables used in the VAR}
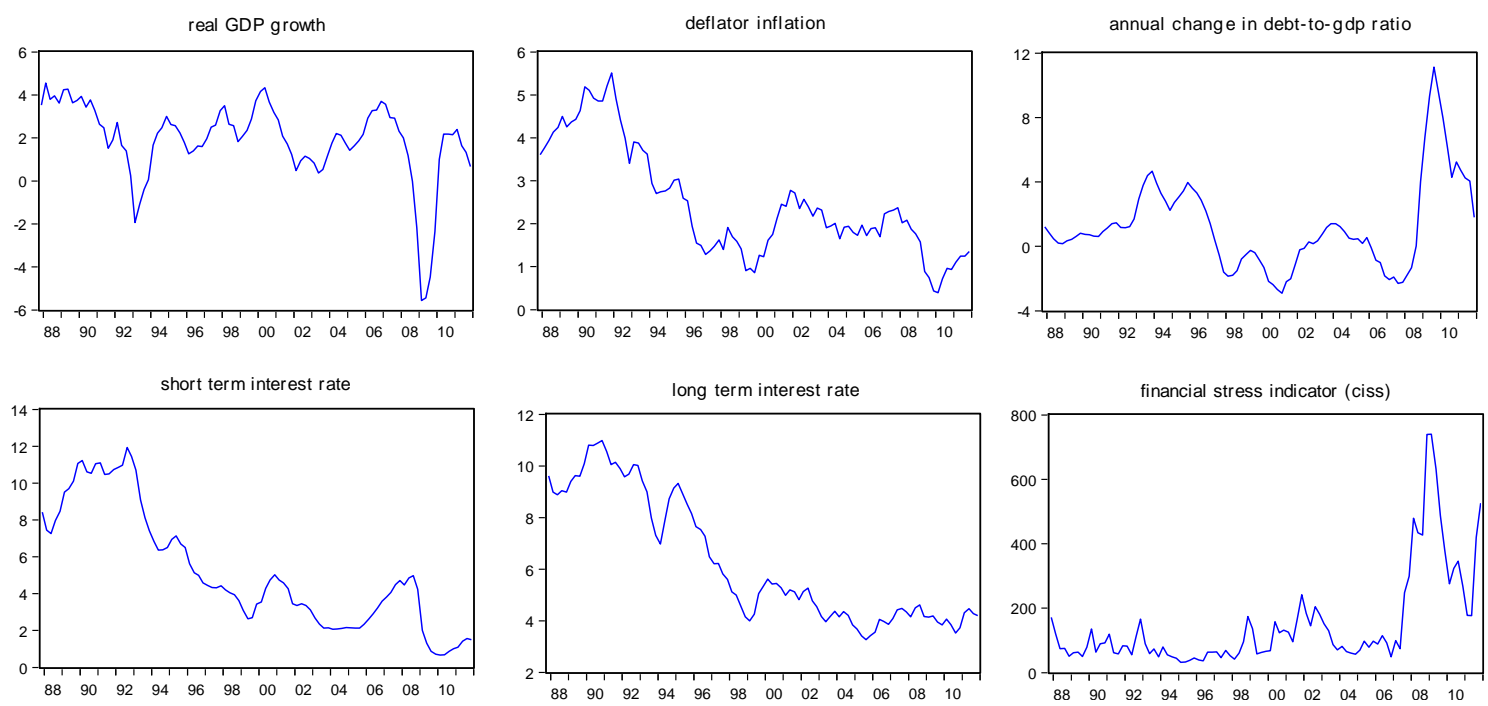


\section{A. 3 - Lag selection criteria}

VAR Lag Order Selection Criteria

Endogenous variables: Y P F L I S

Exogenous variables: $\mathrm{C}$

Sample: 1987Q1 - 2011Q4

Included observations: 96

\begin{tabular}{cccc}
\hline \hline Lag & AIC & SC & HQ \\
\hline \hline 0 & 28.94277 & 29.10304 & 29.00755 \\
1 & 16.42683 & $\mathbf{1 7 . 5 4 8 7 4 *}$ & 16.88033 \\
2 & $\mathbf{1 5 . 7 6 0 0 5 *}^{*}$ & 17.84359 & $\mathbf{1 6 . 6 0 2 2 5 *}$ \\
3 & 15.85670 & 18.90186 & 17.08760 \\
4 & 15.99905 & 20.00584 & 17.61866 \\
\hline \hline
\end{tabular}

* indicates lag order selected by the criterion

AIC: Akaike information criterion

SC: Schwarz information criterion

HQ: Hannan-Quinn information criterion 


\section{A. 4 - Effects of interest rates shocks}

Pre-EMU sub-sample: Q1 1987 - Q4 1998

Response to Cholesky One S.D. Innovations \pm 2 S.E.

Response of $Y$ to

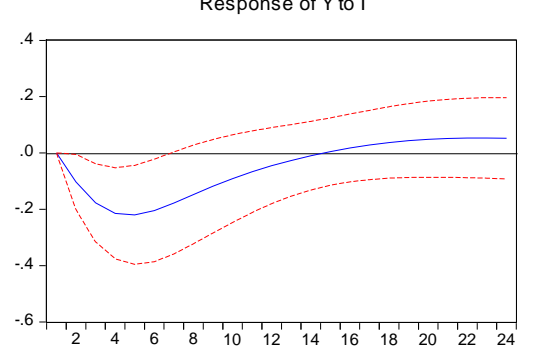

Response of $\mathrm{F}$ to $\mathrm{I}$

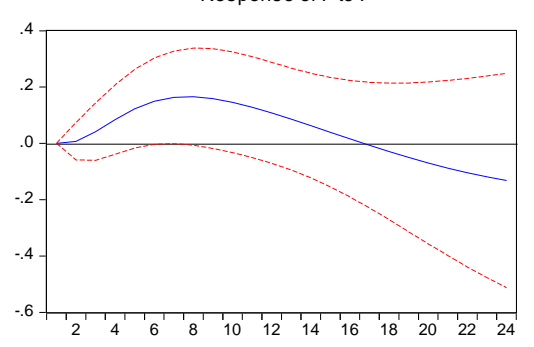

Response of $\mid$ to $\mid$

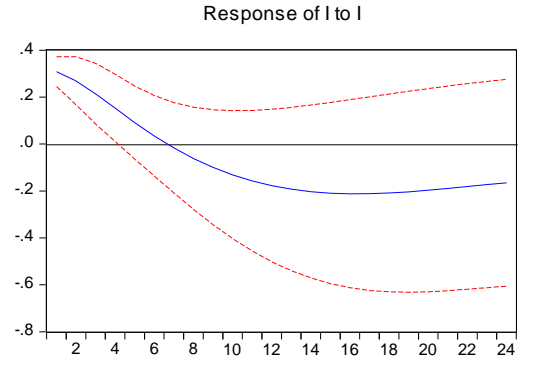

Response of $\mathrm{P}$ to $\mathrm{I}$

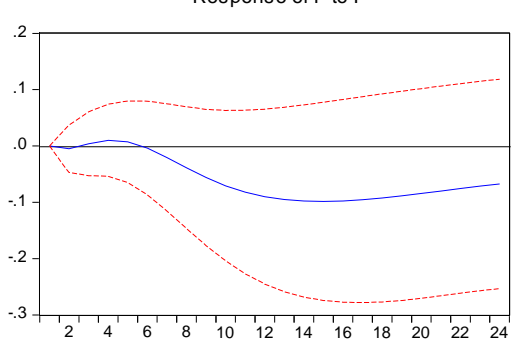

Response of $L$ to I

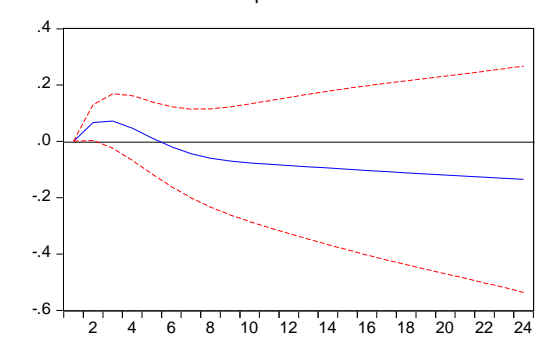

Response of S to I

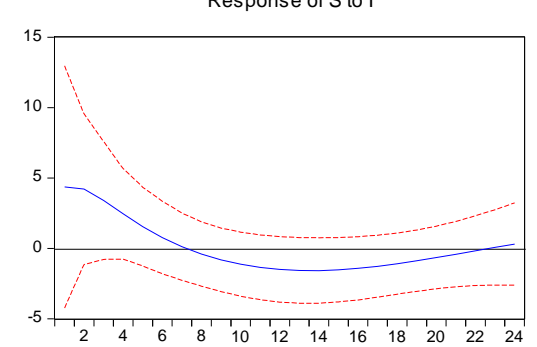

Post-EMU sub-sample: Q1 1999 - Q4 2011

Response to Cholesky One S.D. Innovations \pm 2 S.E.

Response of $Y$ to $I$

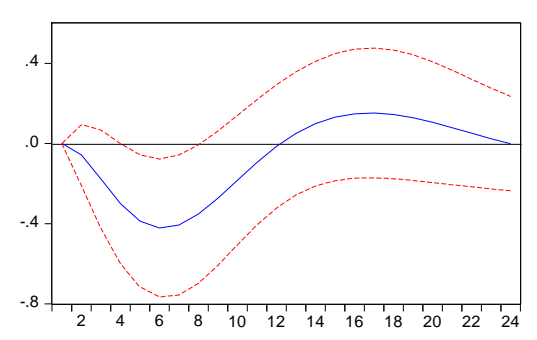

Response of $\mathrm{F}$ to

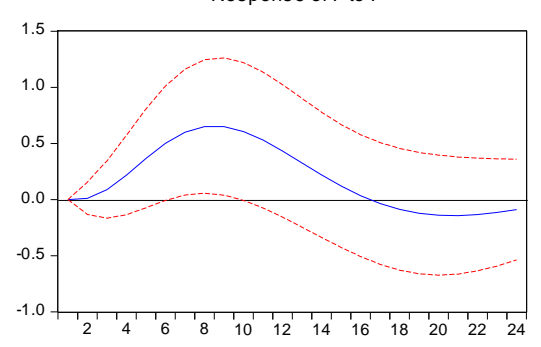

Response of I to I

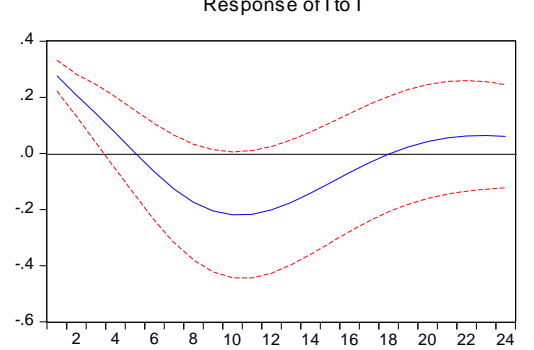

Response of $\mathrm{P}$ to $\mathrm{I}$

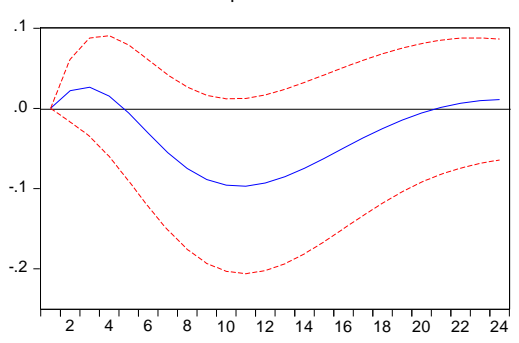

Response of $L$ to 1

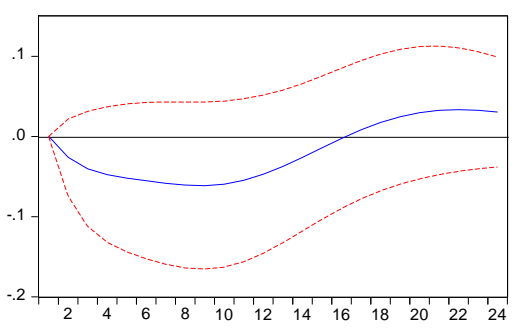

Response of S to I

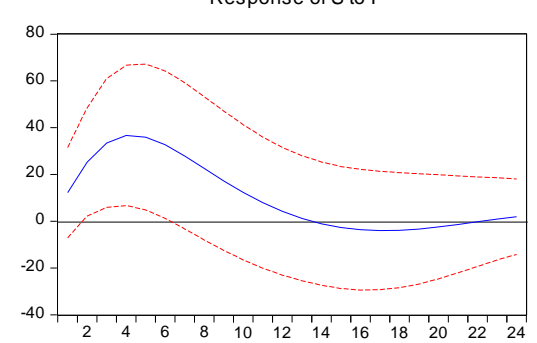


Response to Cholesky One S.D. Innovations \pm 2 S.E.
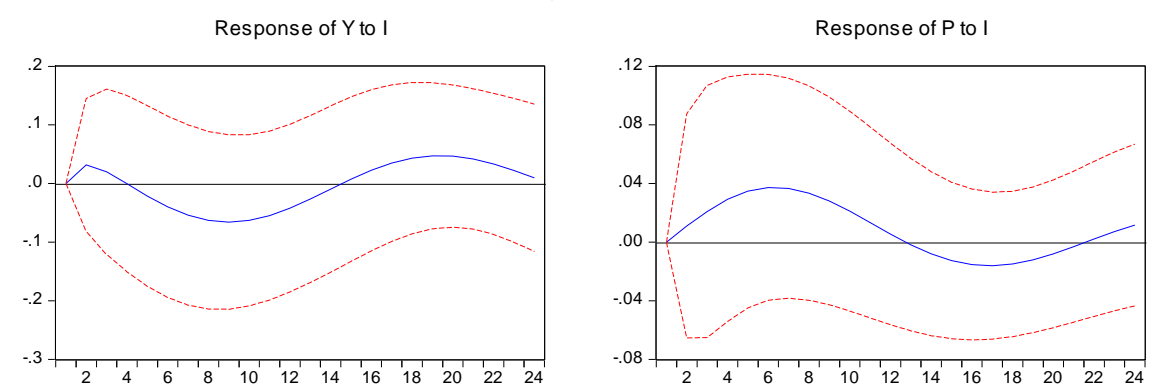

Response of $\mathrm{F}$ to

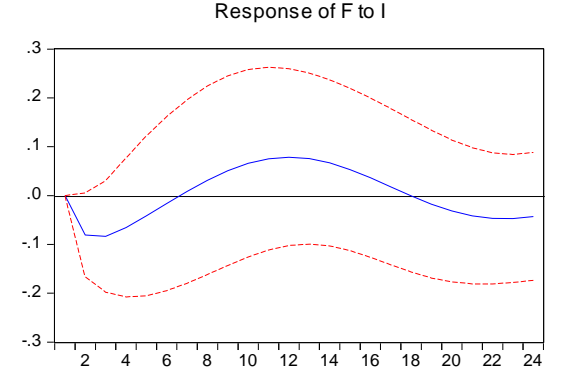

Response of I to I
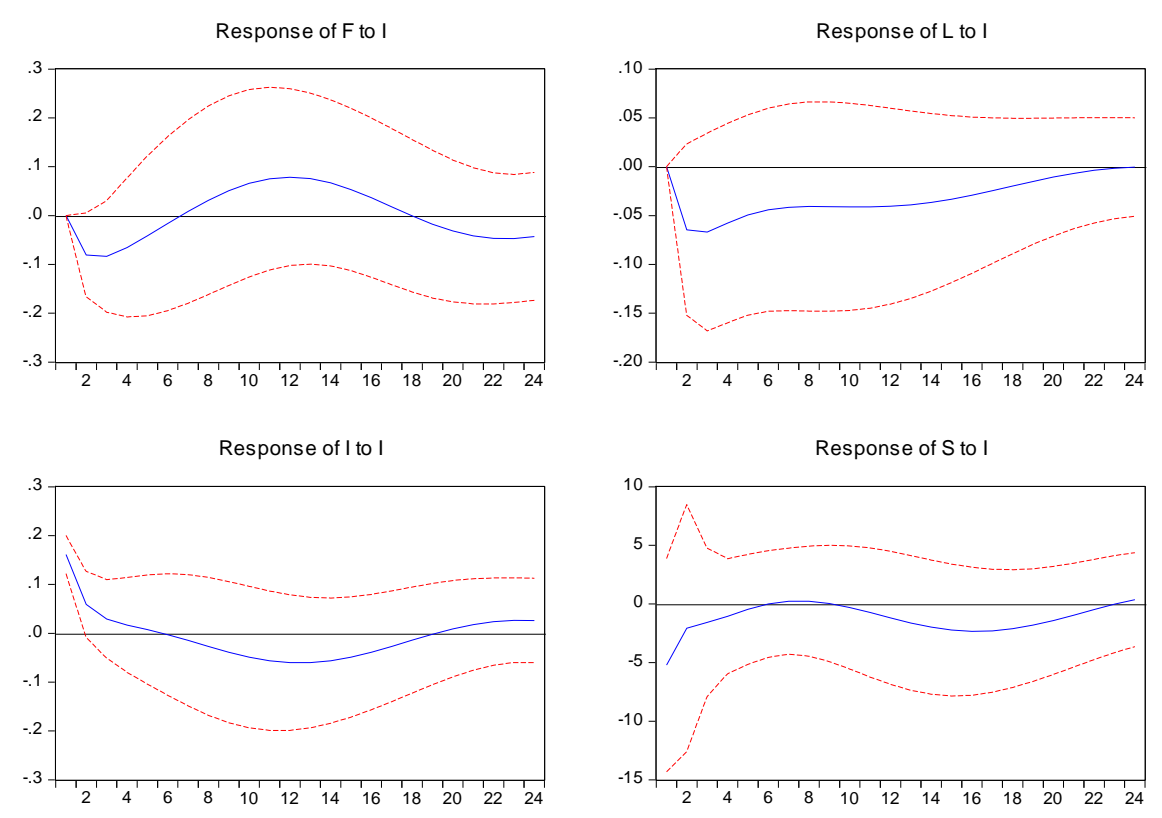

Post-EMU, pre-sovereign debt crisis sub-sample: Q1 1999 - Q4 2009
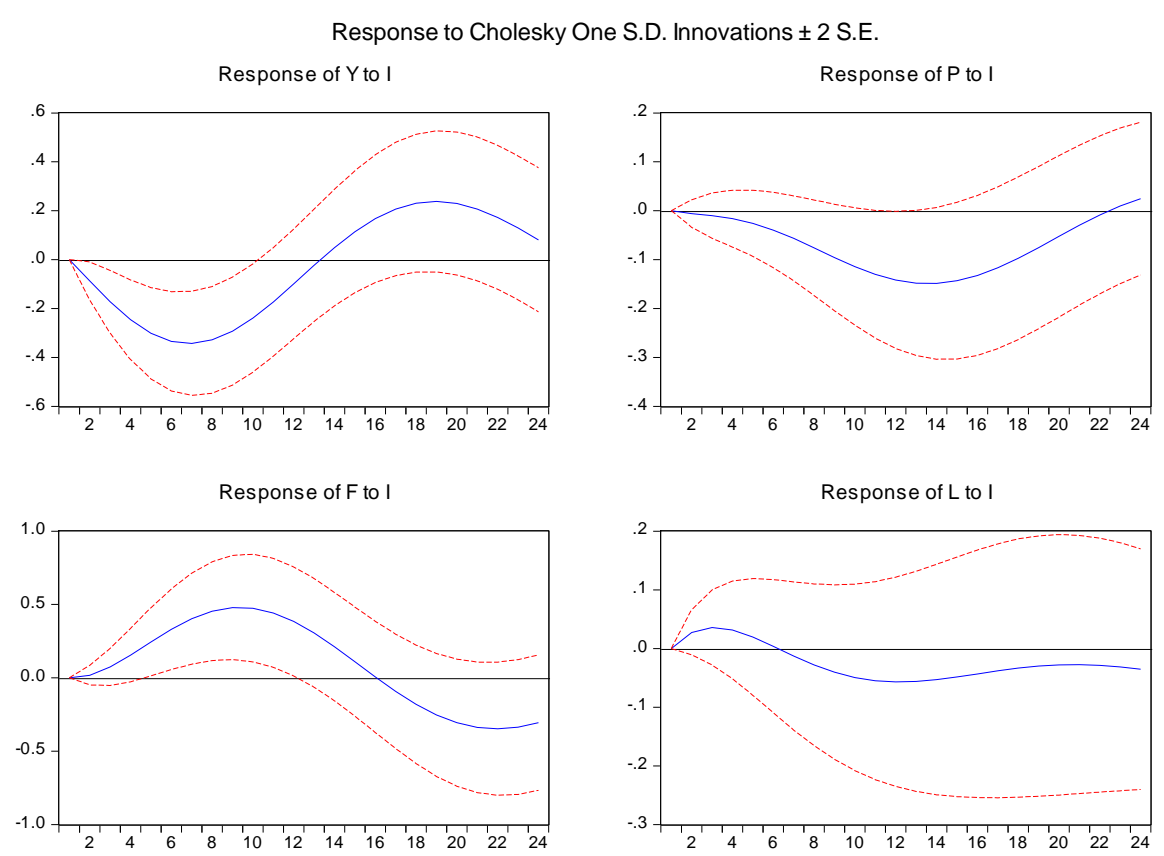

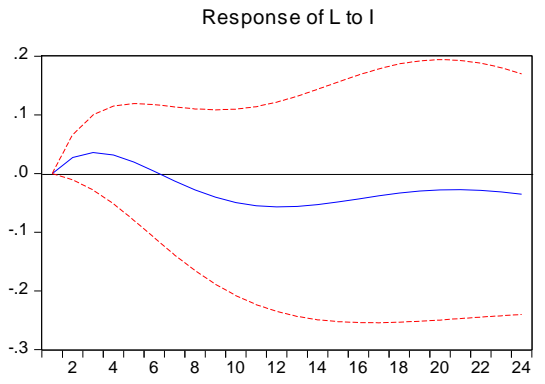

Response of I to I

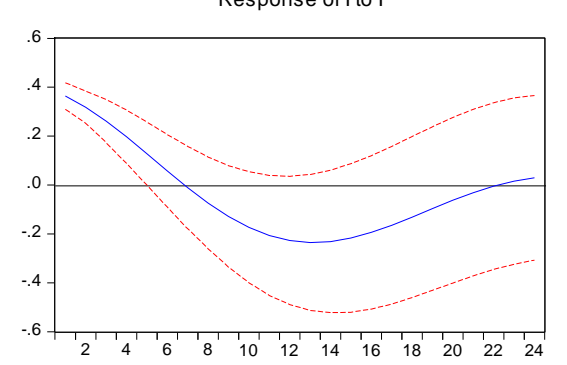

Response of $\mathrm{S}$ to I

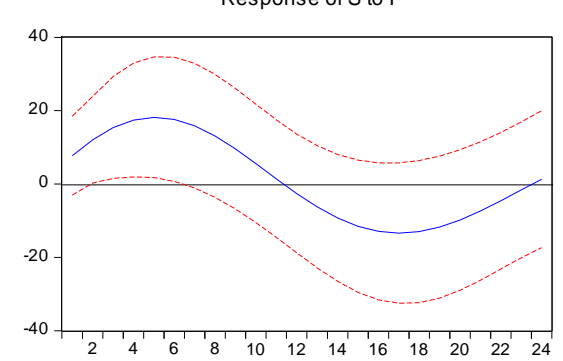


Alternative pre-EMU sub-sample: Q1 1987 - Q1 1996

Response to Cholesky One S.D. Innovations \pm 2 S.E.

Response of $Y$ to I

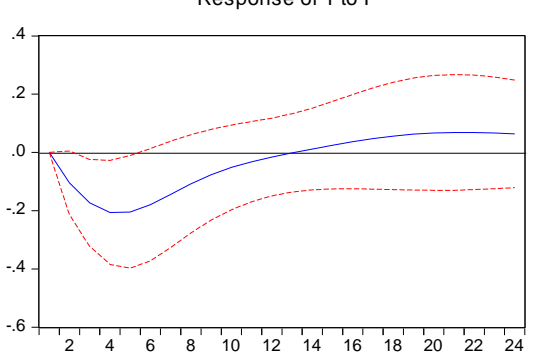

Response of $\mathrm{F}$ to

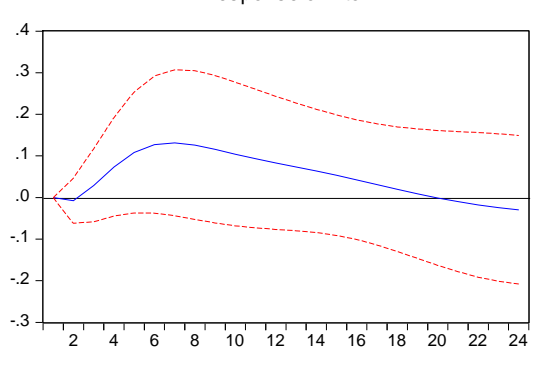

Response of I to I

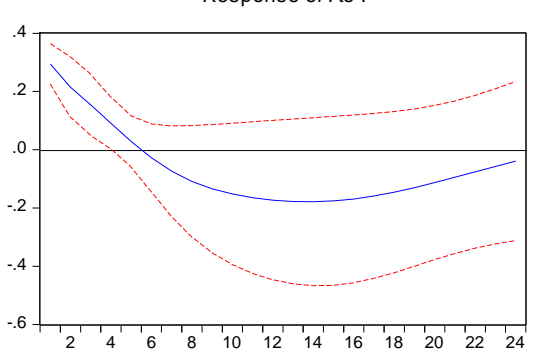

Response of $\mathrm{P}$ to $\mathrm{I}$

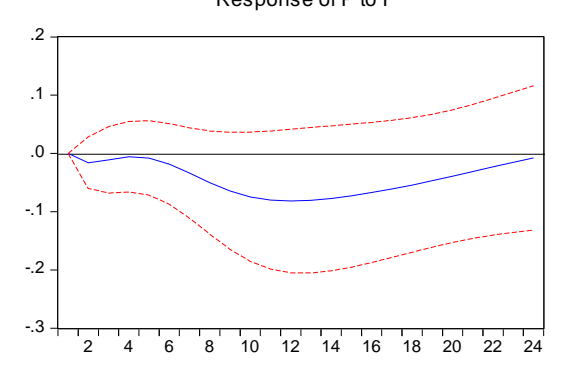

Response of $L$ to

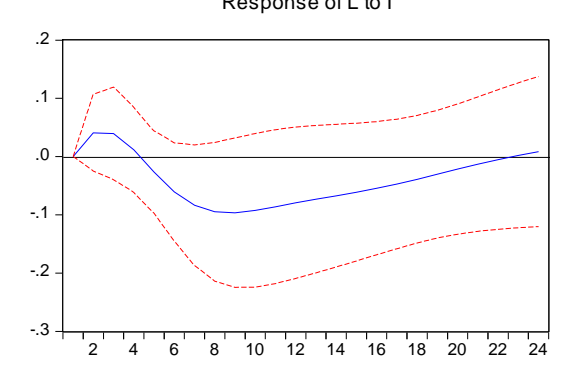

Response of S to I

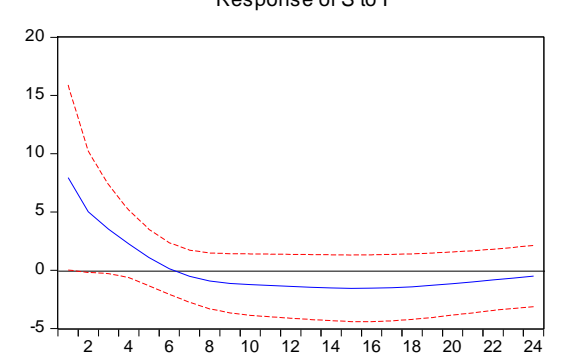




\section{A. 5 - Effects of fiscal shocks}

\section{Pre-EMU sub-sample: Q1 1987 - Q4 1998}

Response to Cholesky One S.D. Innovations \pm 2 S.E.

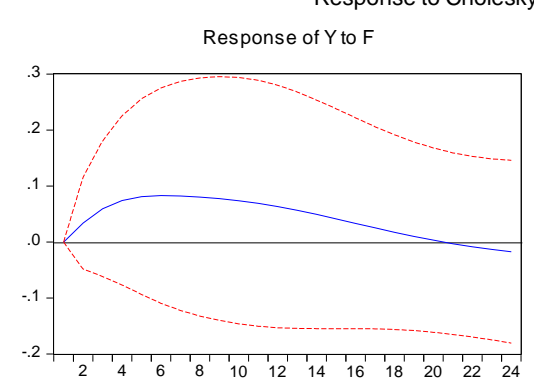

Response of $F$ to $F$

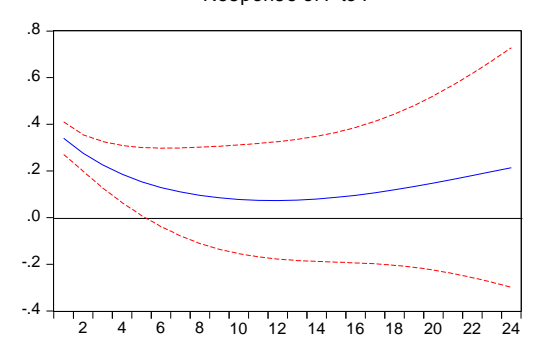

Response of $\mathrm{I}$ to $\mathrm{F}$

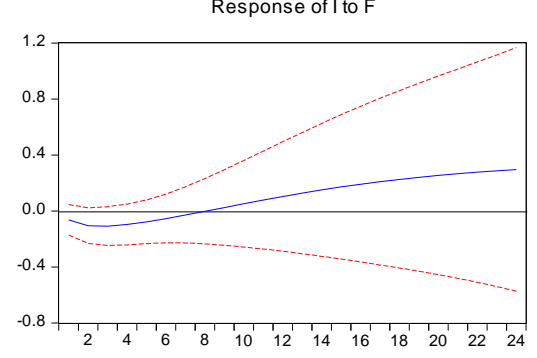

Response of $\mathrm{P}$ to $\mathrm{F}$

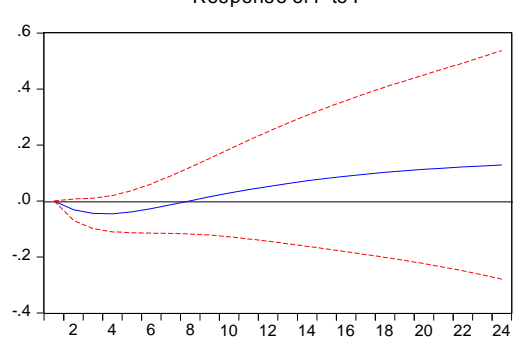

Response of $L$ to $F$

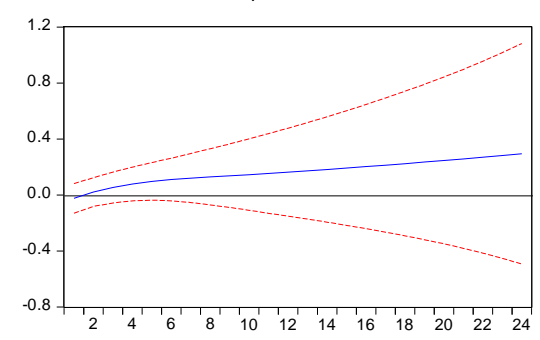

Response of $S$ to $F$

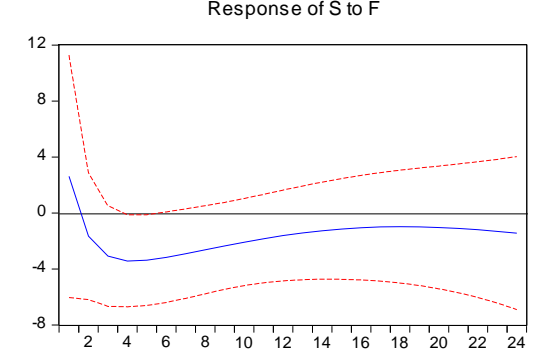

Post-EMU sub-sample: Q1 1999-Q4 2011
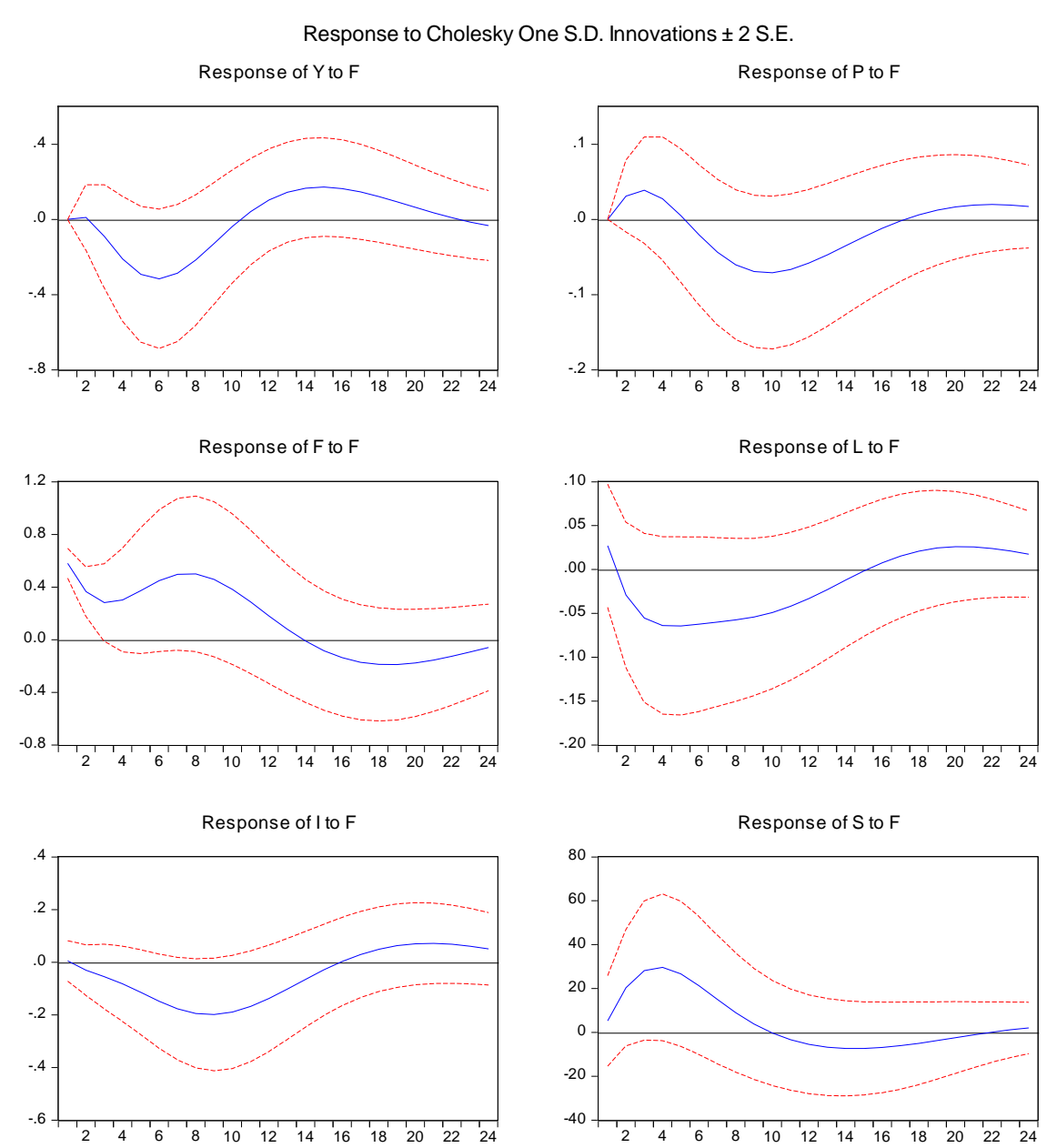
Response to Cholesky One S.D. Innovations \pm 2 S.E. Response of $Y$ to $F$

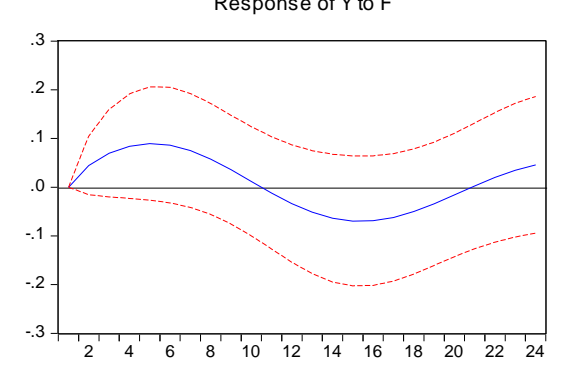

Response of $\mathrm{F}$ to $\mathrm{F}$

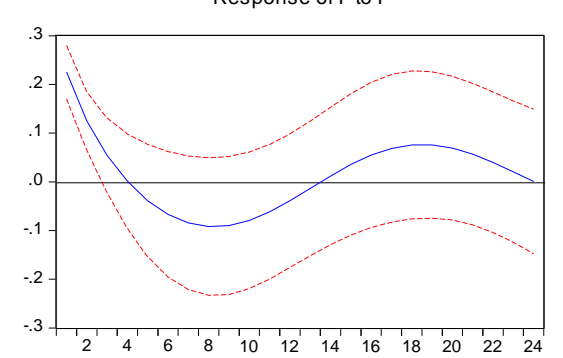

Response of $\mathrm{I}$ to $\mathrm{F}$

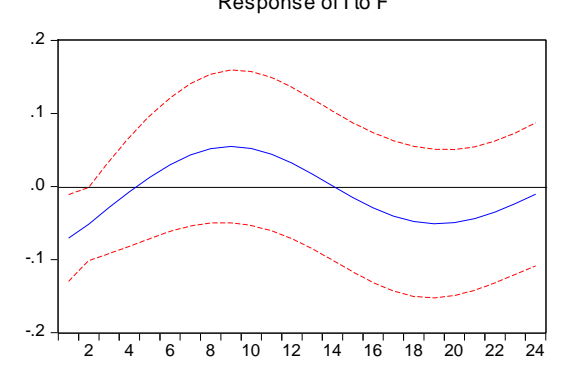

Response of $\mathrm{P}$ to $\mathrm{F}$

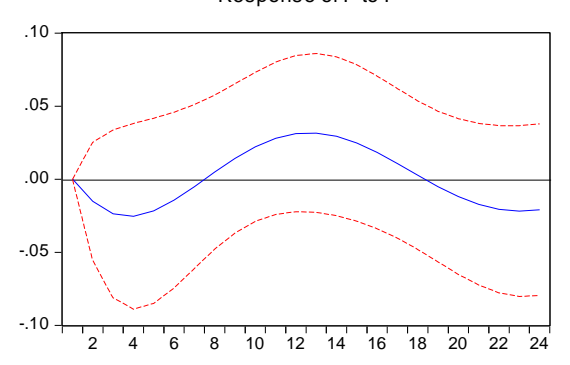

Response of $L$ to $F$

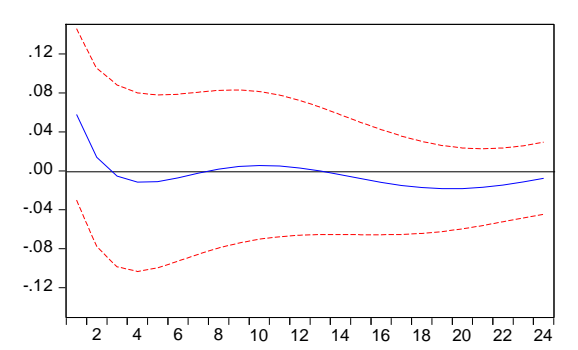

Response of $\mathrm{S}$ to $\mathrm{F}$

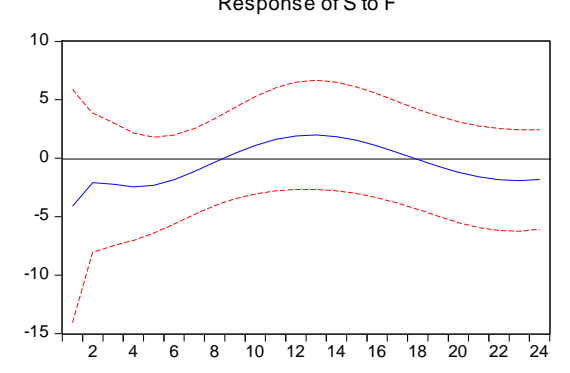

Post-EMU, pre-sovereign debt crisis sub-sample: Q1 $1999-Q 4$ 2009

Response to Cholesky One S.D. Innovations \pm 2 S.E.

Response of $Y$ to $F$

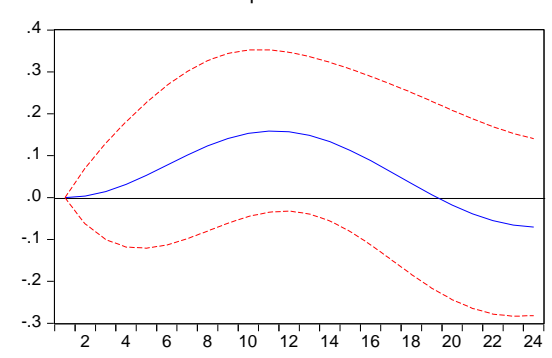

Response of $\mathrm{F}$ to $\mathrm{F}$

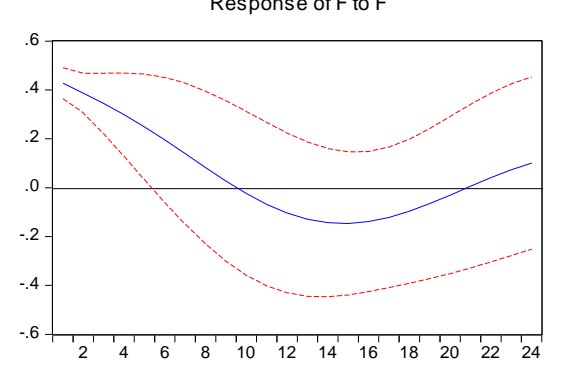

Response of I to $\mathrm{F}$

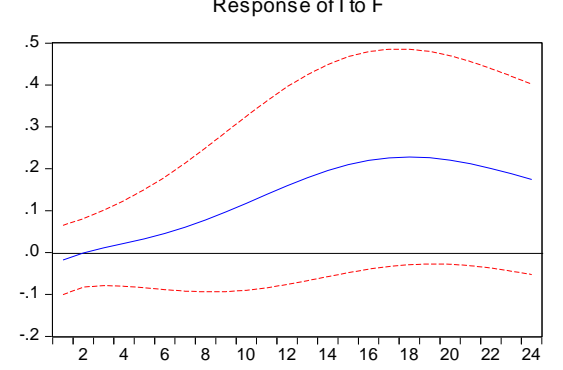

Response of $\mathrm{P}$ to $\mathrm{F}$

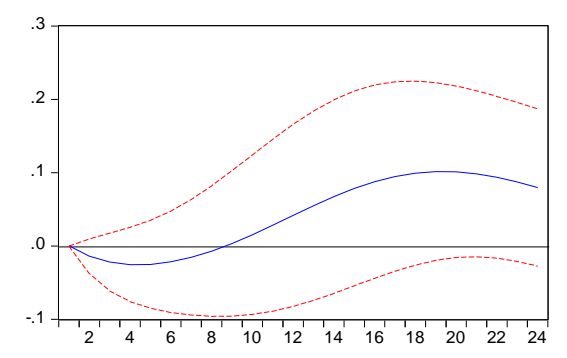

Response of $L$ to $F$

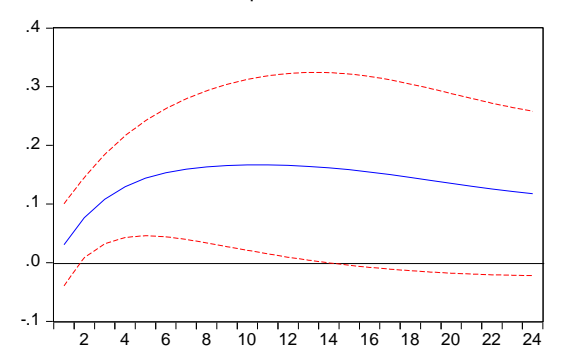

Response of $\mathrm{S}$ to $\mathrm{F}$

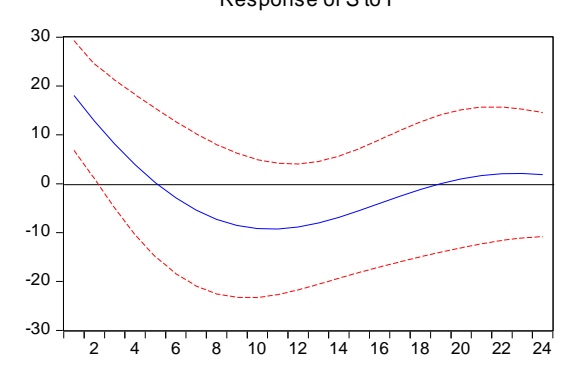


Alternative pre-EMU sub-sample: Q1 1987 - Q1 1996

Response to Cholesky One S.D. Innovations \pm 2 S.E.

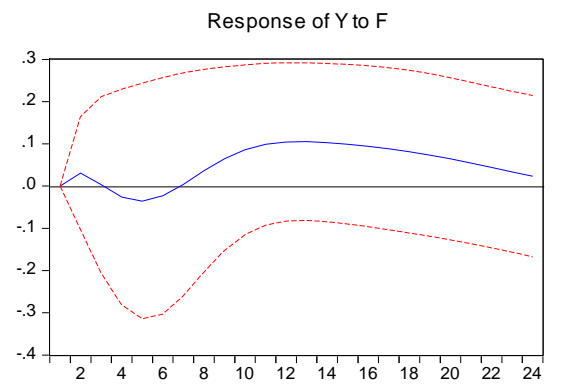

Response of $\mathrm{P}$ to $\mathrm{F}$
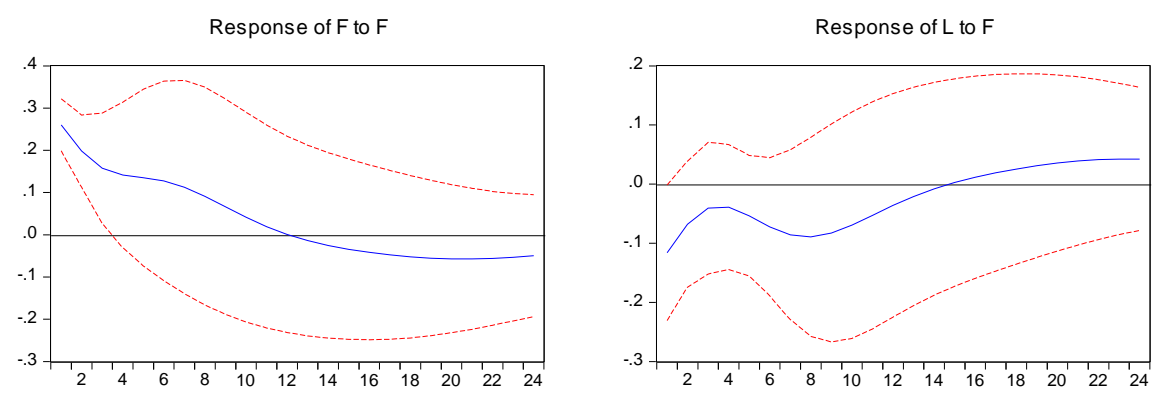

Response of I to $F$

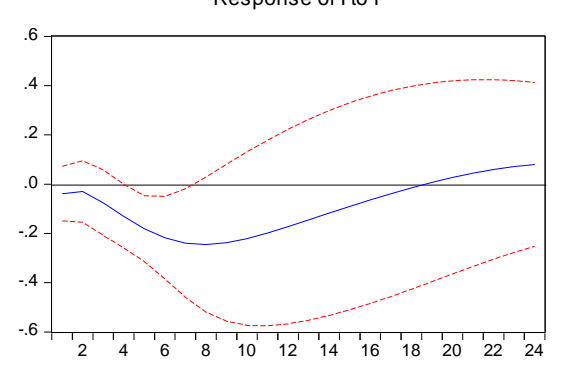

Response of $\mathrm{S}$ to $\mathrm{F}$

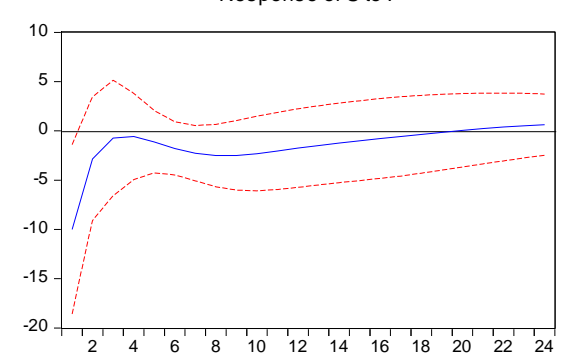




\section{A. 6 - Effects of financial stress shocks}

\section{Pre-EMU sub-sample: Q1 1987 - Q4 1998}

Response to Cholesky One S.D. Innovations \pm 2 S.E.

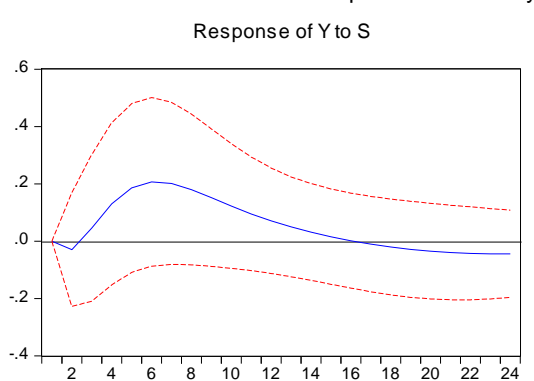

Response of $\mathrm{F}$ to $\mathrm{S}$

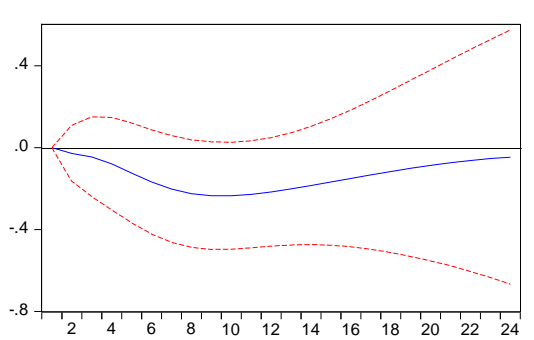

Response of I to $\mathrm{S}$

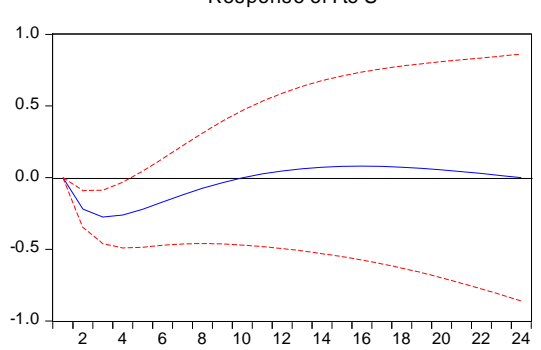

Response of $\mathrm{P}$ to $\mathrm{S}$

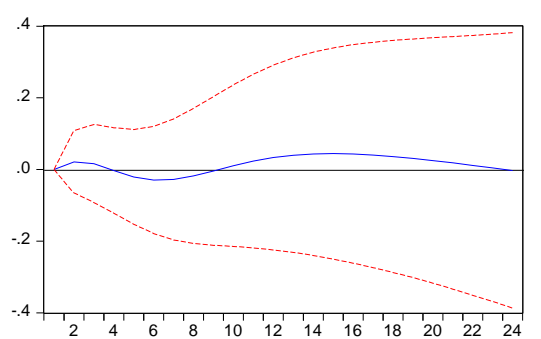

Response of $L$ to $S$

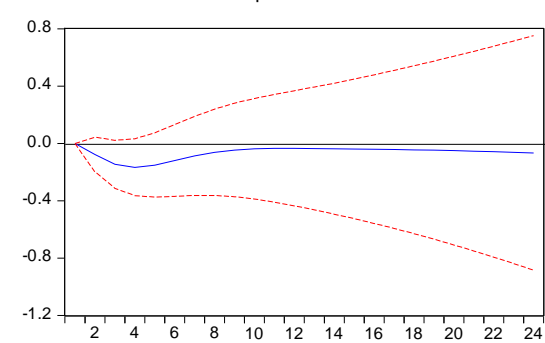

Response of $S$ to $S$

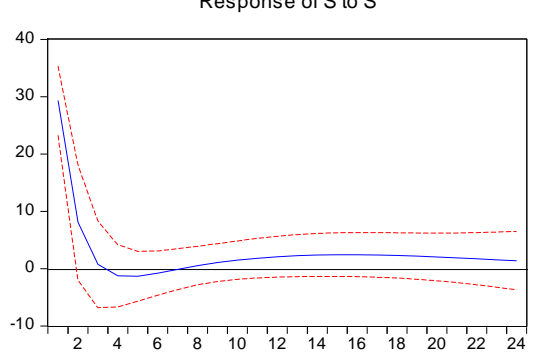

Post-EMU sub-sample: Q1 1999 -Q4 2011

Response to Cholesky One S.D. Innovations \pm 2 S.E. Response of $Y$ to $S$

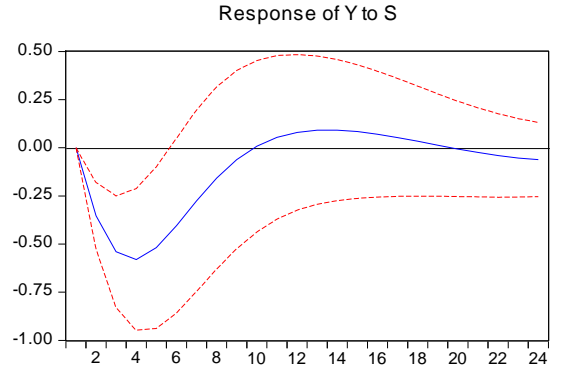

Response of $\mathrm{F}$ to $\mathrm{S}$

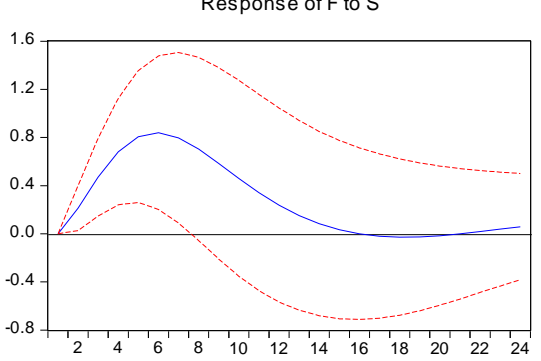

Response of I to $S$

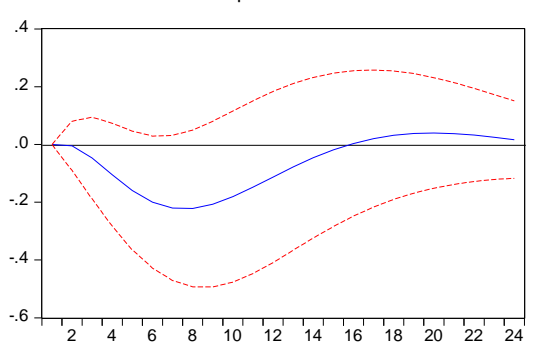

Response of $\mathrm{P}$ to

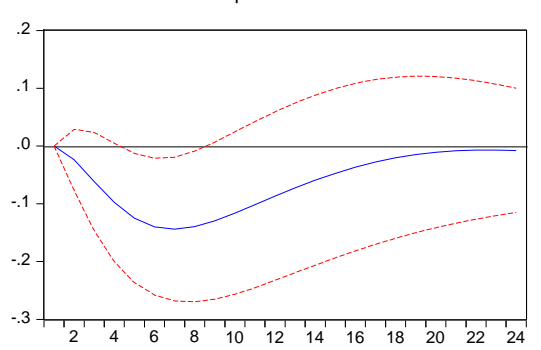

Response of $L$ to $S$

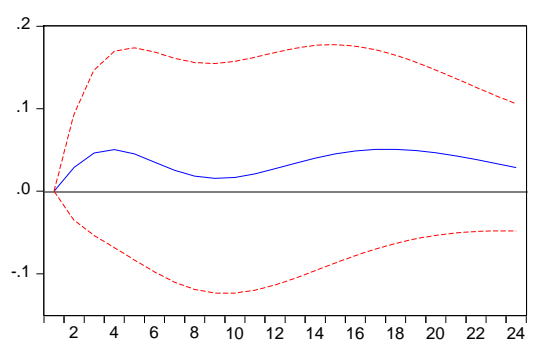

Response of $\mathrm{S}$ to

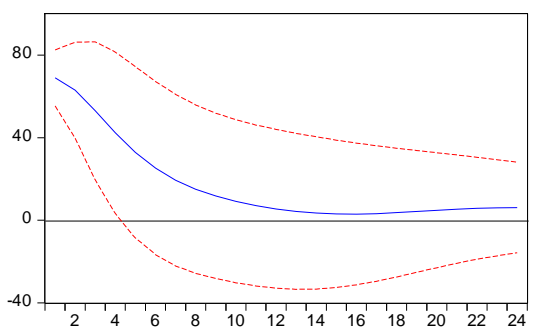


Response to Cholesky One S.D. Innovations \pm 2 S.E. Response of $\mathrm{Y}$ to $\mathrm{S}$

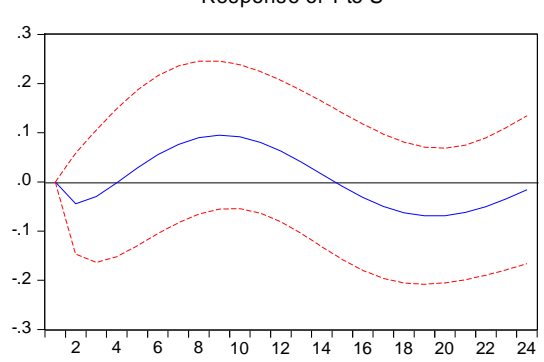

Response of $\mathrm{F}$ to $\mathrm{S}$

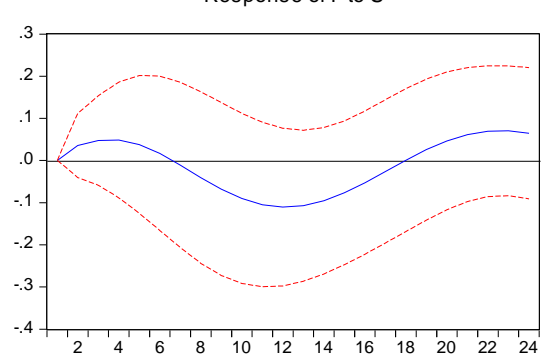

Response of I to $S$

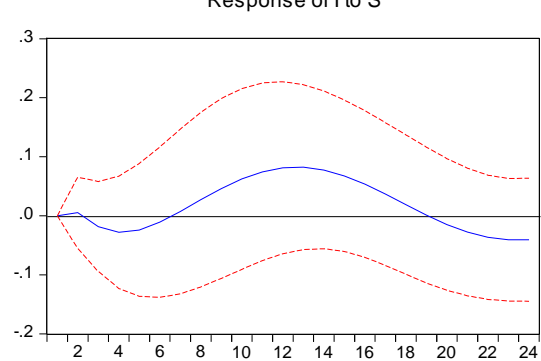

Response of $P$ to $S$

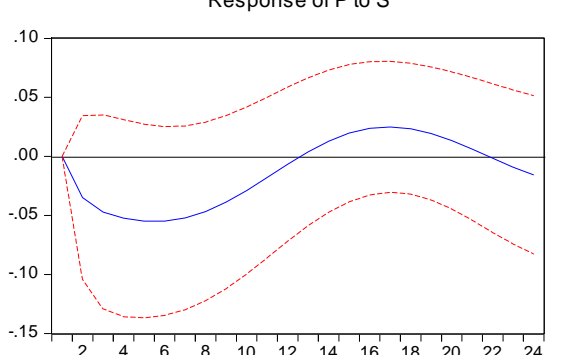

Response of $L$ to $S$

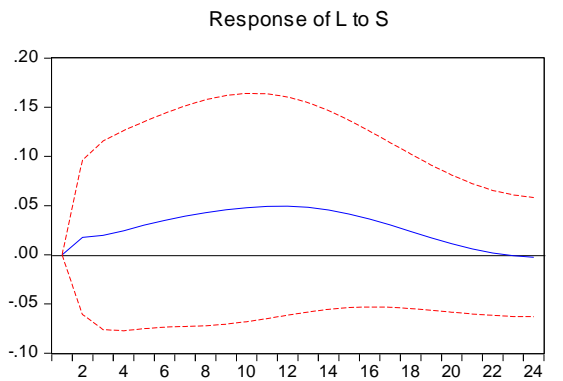

Response of $S$ to $S$

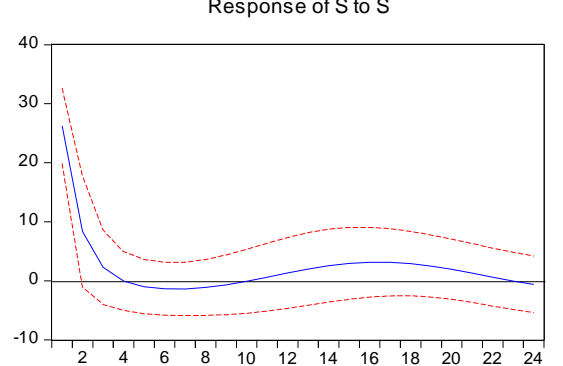

Post-EMU, pre-sovereign debt crisis sub-sample: Q1 1999 -Q4 2009

Response to Cholesky One S.D. Innovations \pm 2 S.E.

Response of $Y$ to $S$

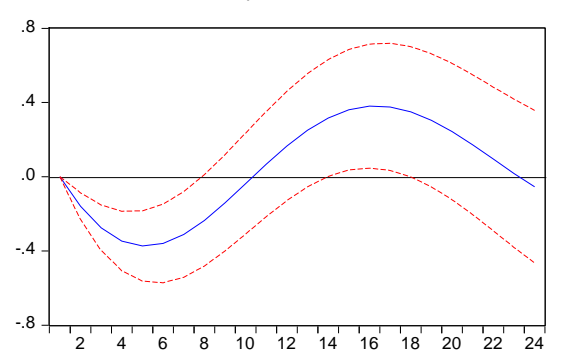

Response of $F$ to $S$

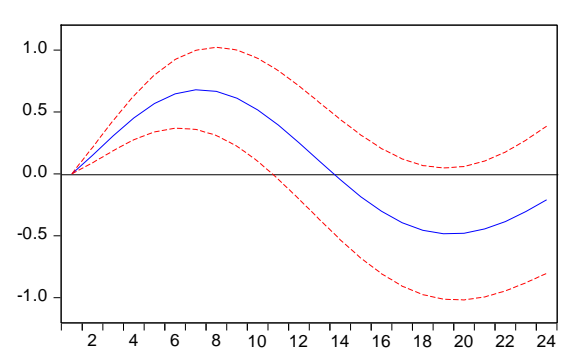

Response of I to $S$

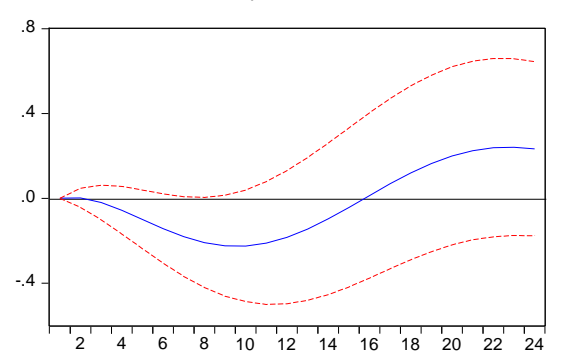

Response of $\mathrm{P}$ to $\mathrm{S}$

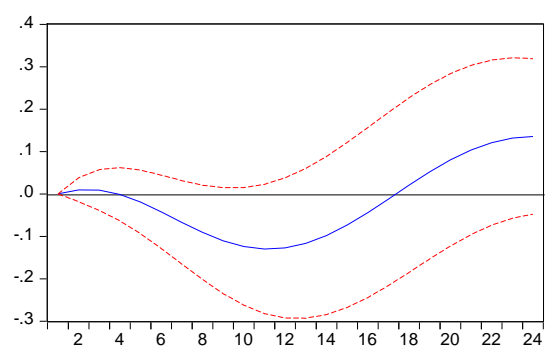

Response of $L$ to $S$

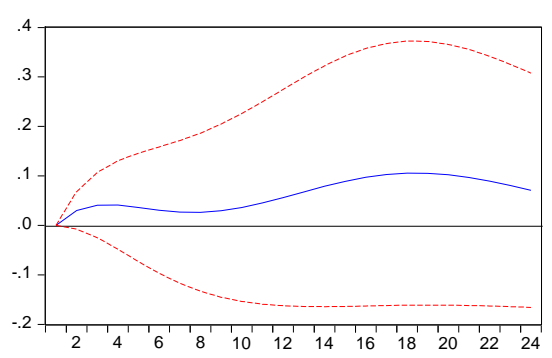

Response of $S$ to $S$

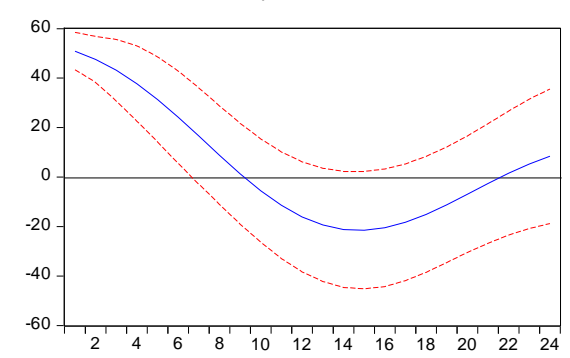


Alternative pre-EMU sub-sample: Q1 1987 -Q1 1996

Response to Cholesky One S.D. Innovations \pm 2 S.E.

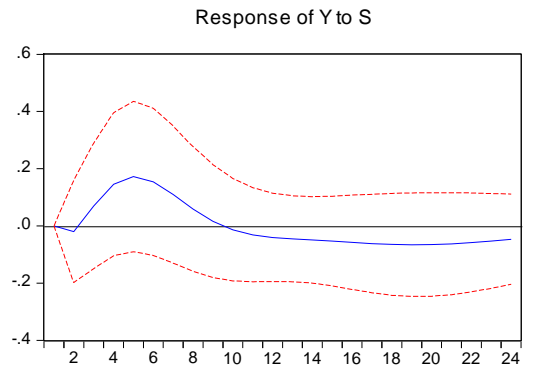

Response of $\mathrm{F}$ to $\mathrm{S}$

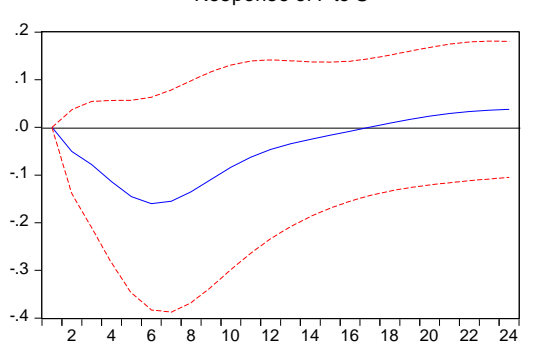

Response of I to $S$
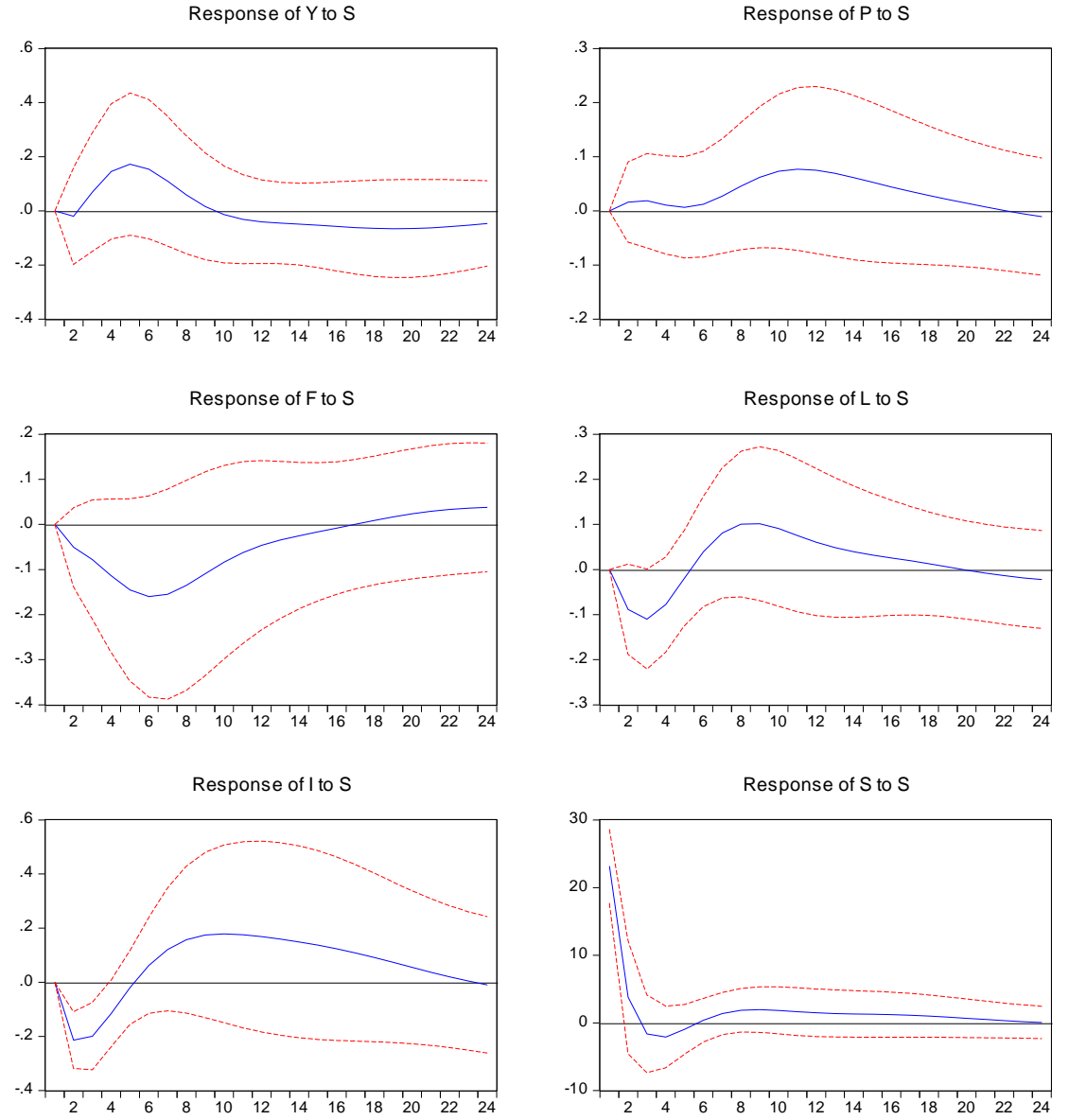

Response of $L$ to $S$

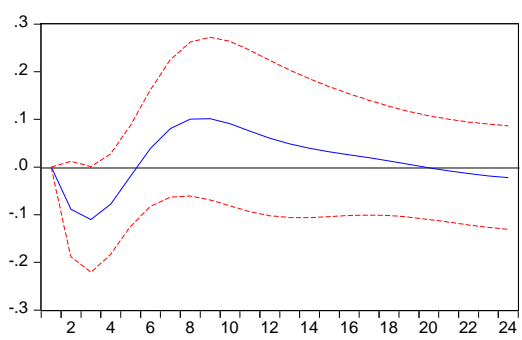

Response of $\mathrm{S}$ to $\mathrm{S}$

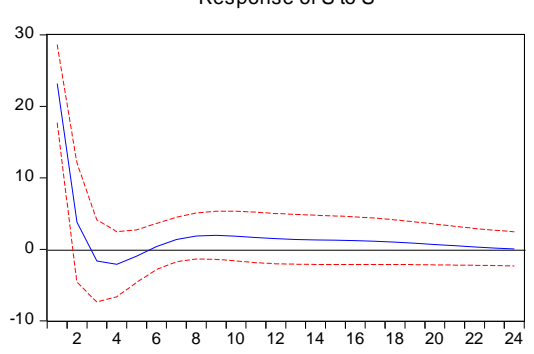

